\title{
A Ghost in the House of Justice: Death and the Language of the Law
}

\author{
Shoshana Felman*
}

\section{INTRODUCTION}

A witness faints on the stand during the Eichmann trial. This Essay will explore the meaning of this unexpected legal moment, and will ask: Is the witness's collapse relevant-and if so, in what sense-to the legal framework of the trial? How does this courtroom event affect the trial's definition of legal meaning in the wake of the Holocaust? Under what circumstances and in what ways can the legal default of a witness constitute a legal testimony in its own right?

I will present, first, Hannah Arendt's reading of this episode, and will later contrast her reading with my own interpretation of this courtroom scene. Still later, I will analyze the judges' reference to this scene.

These different and successive analytical and textual vantage points will be systematically and commonly subordinated to the following three overriding theoretical inquiries:

1) What is the role of human fallibility in trials?

2) Can moments of disruption of convention and of discourse-moments of unpredictability that take the legal institution by surprise--nevertheless contribute to the formulation of a legal meaning?

3) How can such moments shed light on (what I set out to highlight as) the key structural relation between law and trauma? What tools does the law have- and what are the law's limits - in adjudicating massive death and in articulating legal meaning out of massive trauma?

* Copyright (C) 2001 by Shoshana Felman, Thomas E. Donnelley Professor of French and Comparative Literature, Yale University. This material may not be reprinted, reproduced, photocopied, quoted or cited, in whole or in part, without express permission of the author. All rights reserved. 


\section{PaRT ONE: DeATH AND THE LANGUAGE OF THE LAW}

\section{Two Visions of Historic Trial}

In the postwar trials that attempted to judge history and to resolve the horrors of administrative massacre in the wake of the unprecedented trauma of the Second World War, two antithetical legal visions of historic trial have emerged: that of the Nuremberg trials in 1945, and that of the Eichmann trial in 1961. The difference between these two paradigms of historic trial derived from their divergent evidentiary approach: The Nuremberg prosecution made a decision to shun witnesses and base the case against the Nazi leaders exclusively on documents, whereas the prosecution in the Eichmann trial chose to rely extensively on witnesses as well as documents to substantiate its case. While both prosecutors similarly used the trial to establish what in Nietzsche's term can be called a "monumental [legal] history," Nuremberg was a monumental documentary case, whereas the Eichmann trial was a monumental testimonial case (despite its equally substantial use of documents). In 1954, the chief prosecutor and the architect of the Nuremberg trials, Justice Robert Jackson, retrospectively explained the grounds for his choice of proof:

The prosecution early was confronted with two vital decisions... One was whether chiefly to rely upon living witnesses or upon documents for proof of the case. The decision ... was to use and rest on documentary evidence to prove every point possible. The argument against this was that documents are dull, the press would not report them, the trial would become wearisome and would not get across to the people. There was much truth in this position, I must admit. But it seemed to me that witnesses, many of them persecuted and hostile to the Nazis, would always be chargeable with bias, faulty recollection, and even perjury. The documents could not be accused of partiality, forgetfulness, or invention, and would make the sounder foundation, not only for the immediate guidance of the tribunal, but for the ultimate verdict of history. The result was that the tribunal declared, in its judgement, "The case, therefore, against the defendants rests in a large measure on documents of their own making."

1. Friedrich Nietzsche, The USE AND ABUSE OF HISTORY FOR LIFE 12-17 (Adrian Collins trans., The Liberal Arts Press 1957) (1949).

2. Robert Jackson, Introduction to WHITNEY HaRRIS, TYRANNY ON TRIAL: THE EVIDENCE AT 


\section{Fragile Evidence}

The documentary approach matched the bureaucracy of the Nazi regime and was particularly suitable to the exposure of the monstrous bureaucratic nature of the crime and of its alibis. The testimonial approach was necessary for the full disclosure of the thought-defying magnitude of the offense against the victims, and was particularly suitable to the valorization of the victims' narrative perspective.

The reason he decided to add living witnesses to documents, the Israeli prosecutor Gideon Hausner explained, was that the Nuremberg trials had failed to transmit, ${ }^{3}$ or to impress on human memory and "on the hearts of men" the knowledge and the shock of what had happened. The Eichmann trial sought, in contrast, not only to establish facts but to transmit (transmit truth as event and as the shock of an encounter with events, transmit history as an experience). The tool of law was used not only as a tool of proof of unimaginable facts, but, above all, as a compelling medium of transmission-as an effective tool of national and international communication of these thought-defying facts. In comparing thus the evidentiary approach of Nuremberg to his own legal choices, the Israeli prosecutor wrote:

There is an obvious advantage in written proof; whatever it has to convey is there in black and white... Nor can a document be ... broken down in cross-examination. It speaks in a steady voice; it may not cry out, but neither can it be silenced.

This was the course adopted at the Nuremberg trials.... It was... efficient.... But it was also one of the reasons why the proceedings there failed to reach the hearts of men.

In order merely to secure a conviction, it was obviously enough to let the archives speak... But I knew we needed more than a conviction; we needed a living record of a gigantic human and national disaster.

NUREMBERG, at xxix, xxxv-xxxvi (1954).

3. 'Novelist Rebecca West, covering the first 'historic' Nuremberg trial for the New Yorker, found it insufferably tedious," writes MARK OSIEL, MASS ATROCITY, COLLECTIVE MEMORY, AND THE LAW 91 (2000) (referring to Rebecca West, Extraordinary Exile, NEW YORKER, Sept. 7, 1946, at 34). "This reaction was not uncommon," Osiel continues:

As one reporter notes: "It was the largest crime in history and it promised the greatest courtroom spectacle. [But] ... [w]hat ensued was an excruciatingly long and complex trial that failed to mesmerize a distracted world. Its mass of evidence created boredom, mixed occasionally with an abject horror before which ordinary justice seemed helpless."

Id. at 91 (quoting Alex Ross, Watching for a Judgment of Real Evil, N.Y. TIMES, Nov. 12, 1995, § 2 at 37. 
In any criminal proceedings the proof of guilt and the imposition of a penalty, though all-important, are not the exclusive objects. Every trial also ... tells a story.... Our perceptions and our senses are geared to limited experiences.... We stop perceiving living creatures behind the mounting totals of victims; they turn into incomprehensible statistics.

It was beyond human powers to present the calamity in a way that would do justice to six million tragedies. The only way to concretize it was to call surviving witnesses, as many as the framework of the trial would allow, and to ask each of them to tell a tiny fragment of what he had seen and experienced.... Put together, the various narratives of different people would be concrete enough to be apprehended. In this way I hoped to superimpose on a phantom a dimension of reality. ${ }^{4}$

Because of the differences in their evidentiary approach, the Nuremberg trials made a more solid contribution to international law, in setting up a binding legal precedent of crimes against humanity; the Eichmann trial made a greater impact on collective memory. The two trials dramatize the difference between human and non-human evidence. Jackson desires to exclude human vulnerability both from the process of the law and from the exercise of judgment. He thus protects the courtroom from the death it talks about. Because Jackson wants his legal evidence to be literally invulnerable, he has to give preference to non-human and non-living evidence. "The documents could not be accused of partiality, forgetfulness, or invention." "[W]itnesses," on the other hand, "many of them persecuted," "would always be chargeable with bias, faulty recollection, and even perjury."

In choosing, on the contrary, to include as evidence the previously excluded, fragile testimony of the persecuted, the Eichmann trial quite specifically gives legal space to the potential legal failings and shortcomings Jackson fears. It consciously embraces the vulnerability, the legal fallibility and the fragility of the human witness. Paradoxically, it is precisely the witness's fragility that is called upon to testify and to bear witness. $^{6}$

4. Gideon HAUSNER, JUSTICE IN JeRUSALEm 291-92 (1968).

5. Jackson, supra note 2 , at $\mathrm{xxxv-xxxvi.}$

6. In a short text called The Witness, Borges writes:

Deeds which populate the dimensions of space and which reach their end when someone dies may cause us wonderment, but one thing, or an infinite number of things, dies in every final agony, unless there is a universal memory.... What will die with me when I die, what pathetic and fragile form will the world lose?

JORGE LUIS BORGES, The Witness, in LABYRNTHS: SELECTED STORIES AND OTHER WRITINGS 243, 
An Oath to the Dead (A Pseudonym)

Nowhere was this fragile essence of the human testimony more dramatically exemplified and more acutely tested than when, in one of the most breathtaking moments of the trial, a witness fainted on the stand.

He was called to testify because he was a crucially relevant eyewitness: He met Eichmann in Auschwitz. ${ }^{7}$ But he collapsed before he could narrate this factual encounter. His testimony thus amounted to a legal failure, the kind of legal failure Jackson feared. And yet this legal moment of surprise, captured on videotape, ${ }^{8}$ has left an indelible mark on the trial and has impressed itself on visual and historic memory. This courtroom scene has since been broadcast many times on radio and television. Despite the repetition, the power of this legally compelling moment does not wane and its force of astonishment does not diminish and does not fade. It has remained a literally unforgettable key-moment of the trial, a signal or a symbol of a constantly replayed and yet ungrasped, ungraspable kernel of collective memory. ${ }^{9}$ I propose to try to probe here the significance of this mysteriously material kernel.

Who was this witness? He happened to be a writer. He was known under the pseudonym Ka-Tzetnik [K-Zetnik]. ${ }^{10} \mathrm{He}$ saw himself as a messenger of the dead, a bearer of historical meaning he had the duty to preserve and to transmit. K-Zetnik is a slang word meaning a concentration camp inmate, one identified not by name but by the number the Nazis tattooed on each inmate's arm. "I must carry this name," KZetnik testified during the Eichmann trial, "as long as the world will not

243 (1962).

It is because humans, unlike documents, do not endure that the Eichmann trial calls upon each witness to narrate the singular story that will die when he or she dies. Transience is inscribed within this legal process as the witness's death is, from the start, implicitly inscribed within each testimony. While documents-unlike the living witnesses-exclude death as a possibility inherent in the evidence, and while the Nuremberg trials claim authority precisely in the act of sheltering the courtroom from the death it talks about, in the Eichmann trial, on the contrary, "death is the sanction of everything the storyteller has to tell. He has borrowed his authority from death." WALTER BENJAMIN, The Storyteller, in ILlUMINATIONS: ESSAYS AND REFLECTIONS 83, 94 (Hannah Arendt ed., 1968).

7. Attested to by the chief prosecutor's widow in The TRLal of AdOLF EICHMANN, a PBS documentary home video (B3470) (co-produced by ABC News Productions and Great Projects Film Company 1997).

8. The Eichmann trial was the first trial televised in its entirety. The complete trial footage is kept in the archives of the State of Israel.

9. "Our memory," writes Valéry, "repeats to us the discourse that we have not understood. Repetition is responding to incomprehension. It signifies to us that the act of language has not been accomplished." PAUL VALÉRY, Commentaires de Charmes, in I OEUVRES 1507, 1510 (1957) (author's translation).

10. The writer published the English translation of his works under the pseudonym Ka-Tzetnik 135633. An alternative orthography of the author's name, the one used in the trial's English transcripts and in HANNAH ARENDT, EICHMANN IN JERUSALEM (1964), is K-Zetnik (since the name is modeled on the German letters K.Z., pronounced Ka-tzet, from Konzentrationslager, "concentration camp"). This latter orthography is the one I will hereafter use. 
awaken after the crucifying of the nation ... as humanity has risen after the crucifixion of one man." Eichmann trial, several books that were translated into many languages and that had gained celebrity on both sides of the Atlantic. Describing human existence in extermination camps, they were all published as the successive volumes of what the author calls "the Chronicle of a Jewish Family in the Twentieth Century." The name K-Zetnik was selected almost automatically. The author began writing soon after he was liberated from Auschwitz, in a British army hospital in Italy. He had asked the Israeli soldier who was taking care of him to bring him pen and paper: $\mathrm{He}$ had made an oath to the dead, he said, to be their voice and to chronicle their story; since he felt his days were numbered, he had to hurry up; his writing was from the beginning racing against death. For two and a half weeks he hardly got up, writing in one fit his first book. He asked the soldier who was taking care of him to transfer the finished manuscript to Israel. Reading the title "Salamandra" on the first page, the soldier whispered: "You forgot to write the name of the author." "The name of the author?" the surviving writer cried out in reply: "They who went to the crematories wrote this book; write their name: Ka-Tzetnik."12 Thus the soldier added in his handwriting the name that soon was to acquire world fame.

II

Testimony

"What is your full name?" asked the presiding judge. ${ }^{13}$

"Yehiel Dinoor,"14 answered the witness. The prosecutor then

11. Criminal Case 40/61 (Jerusalem), Attorney General v. Eichmann (1961). English translation of the trial transcripts in 3 THE TRIAL OF ADOLF EICHMANN, RECORD OF PROCEEDINGS IN THE DisTRICT COURT OF JeRUALEM, Session No. 68 (June 7, 1961), Jerusalem 1963, at 1237 [hereinafter 3 PROCEEDINGS]. I use here the modified English version quoted in ARENDT, supra note 10, at 224.

12. K-ZETNIK, Tzofan: EDMA 32 (Hakibbutz Hameuchad Publishing House Ltd. 1987) translated in KA-TZETNIK 135633, SHIVITTI: A VISION 16 (Eliyah Nike De-Nur \& Lisa Hermann trans., Harper \& Row 1989).

13. The narrative that follows is a literal transcription of the trial footage (session of K-Zetnik's testimony), as seen in THE TRIAL OF ADOLF EICHMANN, supra note 7. See also 3 PROCEEDINGS, supra note 11 , at 1237 .

14. Yehiel Dinoor was forty-five years old at the time of the trial. Born in Poland as Yehiel Feiner, he changed his legal name to the Hebrew name Dinoor, meaning "a residue from the fire." TOM SEGEV, THE SEVENTH MILLION: THE ISRAELIS AND THE HOLOCAUST 4 (Haim Watzman trans., Hill and Wang 1993) (1991). The name Dinoor is spelled alternatively as Dinur (in the trial's English transcripts, see 3 PROCEEDINGS, supra note 11, at 1237, as De-nur (in the English translation of KZETNIK, SHIVITTI, supra note 12, and consequently, in the English version of SEGEV, THE SEVENTH MILLION, supra), or as Dinoor (in ARENDT, EICHMANN IN JERUSALEM, supra note 10). I am following Arendt's orthography because it best corresponds to the Hebrew pronunciation of the name. 
proceeded.

"What is the reason that you took the pen name K-Zetnik, Mr. Dinoor?"

"It is not a pen name," the witness (now seated) began answering. "I do not regard myself as a writer who writes literature. This is a chronicle from the planet of Auschwitz. I was there for about two years. Time there was different from what it is here on earth. Every split second ran on a different cycle of time. And the inhabitants of that planet had no names. They had neither parents nor children. They did not dress as we dress here. They were not born there nor did anyone give birth. Even their breathing was regulated by the laws of another nature. They did not live, nor did they die, in accordance with the laws of this world. Their names were the numbers, "K-Zetnik so and so ...." They left me, they kept leaving me, left ... for close to two years they left me and always left me behind.... I see them, they are watching me, I see them-"

At this point, the prosecutor gently interrupted: "Mr. Dinoor, could I perhaps put a few questions to you if you will consent?"

But Dinoor continued speaking in a hollow and tense voice, oblivious to the courtroom setting, as a man plunged in hallucination or in a hypnotic trance. "I see them .... I saw them standing in the line. ..."

Thereupon the presiding judge matter-of-factly intervened: "Mr. Dinoor, please, please listen to Mr. Hausner; wait a minute, now you listen to me!"

The haggard witness vacantly got up and without a warning collapsed into a faint, slumping to the floor beside the witness stand.

Policemen ran toward Dinoor to lift his collapsed body, to support him and to carry him out of the courtroom. ${ }^{15}$ The flabbergasted audience remained motionless, staring in disbelief. "Quiet, quiet, quiet!" ordered the presiding judge: "I am asking for silence." A woman's cry was heard from the direction of the audience. A woman wearing sunglasses was coming from the audience toward the unconscious human body held by the policemen, saying she was the witness's wife. "You may approach," the bench conceded. "I do not believe that we can go on." The witness was still limp and lifeless,

15. "All Israel held its breath," Tom Segev will remember thirty years later. "It was the most dramatic moment of the trial, one of the most dramatic moments in the country's history." SEGEV, supra note 14 , at 4 , 
plunged in a deep coma. "We shall take a recess now," declared the presiding judge. "Beth Hamishpat"-["the House of Justice"]shouted the usher, as the audience rose to its feet and the three judges in their black robes were going out. An ambulance was called and rushed the witness to the hospital, where he spent two weeks between life and death in a paralytic stroke. In time, he would recover. ${ }^{16}$

The Legal v. The Poetical

The poet Haim Gouri who covered the trial wrote:

What happened here was the inevitable. [K-Zetnik's] desperate attempt to transgress the legal channel and to return to the planet of the ashes in order to bring it to us was too terrifying an experience for him. He broke down.

Others spoke here for days and days, and told us each his story from the bottom up ... He tried to depart from the quintessential generalization, tried to define, like a meteor, the essence of that world. He tried to find the shortest way between the two planets among which his life had passed.

Or maybe he caught a glimpse of Eichmann all of a sudden and his soul was short-circuited into darkness, all the lights going out.

In a way he had said everything. Whatever he was going to say later was, it turns out, superfluous detail. ${ }^{17}$

This empathetic description which took the testimony on its terms and which, examining it from the vantage point of its own metaphors, poetically reflected back the shock and the emotion of the audience, was a poet's coverage of a fellow poet's testimony. The legal coverage of this episode that Hannah Arendt sent to The New Yorker and later published in her famous Eichmann in Jerusalem was much harsher and much less forgiving.

Arendt disputed fundamentally the way in which the prosecution framed the trial by narratively focusing it on the victims. The state sought to narrate a unique legal story that had never before been told and that had

16. Author's transcription of archival footage as seen in TRIAL OF ADOLF EICHMANN, supra note 7; see also 3 PROCEEDNGS, supra note 11, at 1237.

17. Haim Gouri, Facing the Glass Cage: The Jerusalem Trial 124 (1962) (author's translation). 
failed to be articulated by the Nuremberg trials. To do so, it sought to reconstruct the facts of the Nazi war against the Jews from the victims' point of view and to establish, for the first time in legal history, a "monumental history" not of the victors but of the victims. But Arendt argued that the trial should be focused on the criminal, not on the victim; she wanted it to be a cosmopolitan trial, rather than a Jewish nationalist one; she wanted it to tell the story of totalitarianism and of totalitarian crimes against humanity, rather than the story of the Jewish tragedy and of the crime against the Jewish people. She thus felt impelled to fight Jewish self-centeredness on every point (and on every legal point), and systematically to deconstruct and to decenter the prosecution's monumentalizing victim narrative. In her role as legal reporter for The New Yorker, Arendt finds a stage for exercising her ironic talents not only to dispute the story of the prosecution, but to narrate a contrapuntal legal narrative and to become in turn an ironic or a contrapuntal prosecutor - a prosecutor or (in Nietzsche's terms) a critical historian of the monumental trial. ${ }^{18}$

When she was first confronted with the Nazi crimes during the Nuremberg trials, Arendt believed the magnitude of the phenomenon and the abyss it opened in perception could not be apprehended by the law, except by rupturing its legal framework. She thus wrote in 1946 to Karl Jaspers, her ex-teacher and the continued German friend and interlocutor whom she refound at the end of the war, and through whose sole agency she has now reconnected with her own disrupted German youth:

Your definition of Nazi policy as a crime ("criminal guilt"19) strikes me as questionable. The Nazi crimes, it seems to me, explode the limits of the law; and that is precisely what constitutes their monstrousness. For these crimes, no punishment is severe enough ... . That is, this guilt, in contrast to all criminal guilt, oversteps and shatters any and all legal systems. That is the reason why the Nazis in Nuremberg are so smug. ... And just as inhuman as their guilt is the innocence of the victims. Human beings simply can't be as innocent as they all were in the face of the gas chambers (the most repulsive usurer was as innocent as a newborn child because no crime deserves such a punishment). We are simply not equipped to deal, on a human, political level, with a guilt that is beyond crime and an innocence that is beyond goodness or virtue. This is the abyss that opened up before us as early as $1933 \ldots$ and into which we have finally stumbled. I don't know how we will ever get out of it, for the Germans are

18. See NIETZSCHE, supra note 1. On the difference between the "monumental" and the "critical" versions of the Eichmann trial, see Shoshana Felman, Theaters of Justice: Arendt in Jerusalem, the Eichmann Trial and the Redefinition of Legal Meaning in the Wake of the Holocaust, 27 CRITICAL INQUIRY 201 (2001).

19. Karl Jaspers, The Question of German Guilt (E.B. Ashton trans., Capricorn Books 1961) (1947). 
burdened now with ... hundreds of thousands of people who cannot be adequately punished within the legal system; and we Jews are burdened with millions of innocents, by reason of which every Jew alive today can see himself as innocence personified. ${ }^{20}$

Jaspers does not agree with Arendt. Her attitude, he says, is too poetical. But poetry, he emphasizes, is a much more inadequate, a much less sober tool of apprehension than the law. Poetry by definition is misguided because, by its very nature, it is made to miss the banality of the phenomenon. And the banality, in Jaspers' eyes, is the constitutive feature of the Nazi horror, a feature that should not be mystified or mythified.

You say that what the Nazis did cannot be comprehended as "crime"-I'm not altogether comfortable with your view, because a guilt that goes beyond all criminal guilt inevitably takes on a streak of "greatness" - of satanic greatness-which is, for me, as inappropriate for the Nazis as all the talk about the "demonic" element in Hitler .... It seems to me that we have to see these things in their total banality, in their prosaic triviality, because that's what truly characterizes them. . . . I regard any hint of myth and legend with horror ... . Your view is appealing especially as contrasted with what I see as the false inhuman innocence of the victims. But all this would have to be expressed differently.... The way you express it, you've almost taken the path of poetry. And a Shakespeare would never be able to give adequate form to this material - his instinctive aesthetic sense would lead to falsification of it... There is no idea and no essence here. Nazi crime is properly a subject for psychology and sociology, for psychopathology and jurisprudence only. ${ }^{21}$

From its inception, the future concept of the "banality of evil" emerges as a concept that defines itself by its methodological invalidation of the "the path of poetry," against which it sets up the purposely reductive terminology of "jurisprudence only" and the sobering path of the law (and of the social sciences). "I found what you say about my thoughts on 'beyond crime and innocence' half convincing," Arendt replies at first ambivalently, but she concedes: "We have to combat all impulses to mythologize the horrible."22

When the Eichmann trial is announced fifteen years later, Jaspers and Arendt switch positions. Jaspers maintains that Israel should not try Eichmann because Eichmann's guilt - the subject of the trial-is "larger than law." ${ }^{23}$ Arendt insists that only law can deal with it: "We have no

20. Letter from Hannah Arendt to Karl Jaspers (Aug. 18, 1946), in CORRESPONDENCE: 19261969, at 54 (Lotte Kohler \& Hans Saner eds., Robert \& Rita Kimber trans., 1992) (emphasis added).

21. Letter from Arendt to Jaspers (Oct. 19, 1946), in CORRESPONDENCE, supra note 20, at 62.

22. Letter from Arendt to Jaspers (Dec. 17, 1946), in CORRESPONDENCE, supra note 20, at 68.

23. Letter from Arendt to Jaspers (Dec. 16, 1960), in CORRESPONDENCE, supra note 20, at 413. 
tools to hand except legal ones," she says. ${ }^{24}$ By now, the tool of law is in her hands, par excellence, a tool of apprehension of banality, a tool specifically of demythologization and of deliberate sobering reduction. And if the perpetrator must be banalized and demythologized to be understood in its proper light, so must the victim. No longer can the victim's innocence be allowed to burst the legal frame or to explode the tool of law. No longer can the victim be spared the banality of innocence.

III

\section{Arendt's Contrapuntal Tale}

Arendt reserves some of her harshest language and some of her fiercest irony in Eichmann in Jerusalem for the description of K-Zetnik's unsuccessful court appearance. Indeed, nowhere is Arendt's role as contrapuntal, critical historian of the trial more clearly and more blatantly expressed than in her narration of this episode. Arendt views K-Zetnik's failure on the stand as symptomatic of the general misfire of the trial. She blames this general misfire on the misdirections and the blunders of the prosecution, whose witness has symbolically defaulted through its own fault.

Generally, Arendt makes three objections to the prosecution's choice of witnesses:

1) Contrary to legal rules of evidence, the witnesses are not selected for their relevance to Eichmann's acts but for the purposes of the depiction of a larger picture of the Nazi persecution of the Jews. "This case," writes Arendt disapprovingly, "was built on what the Jews had suffered, not on what Eichmann had done." 25 This depiction by the victims of the persecution they had suffered and their reconstruction of the global history of their victimization is irrelevant in Arendt's eyes. K-Zetnik as a witness seems to Arendt to exemplify the witnesses' irrelevance.

2) Contrary to Arendt's judgment and to her taste, the prosecution prefers witnesses of prominence. It has a predilection, in particular, for famous writers such as K-Zetnik and Abba Kovner. The former's testimony was a fiasco. The latter, Arendt caustically notes, "had not so much testified as addressed an audience with the ease of someone who is used to speaking in public and resents interruptions from the floor." ${ }^{26}$ In Arendt's eyes, a witness' fame is a corrupting element of the judicial process. The writer's

24. Letter from Arendt to Jaspers (Dec. 23, 1960), in CORRESPONDENCE, supra note 20, at 417.

25. ARENDT, supra note 10 , at 6 .

26. Id. at 230 . 
professional articulateness compromises the truth of the testimony in turning testimonies into speeches. Such is K-Zetnik's case.

3) The prosecution's choice of witnesses is guided, Arendt charges, by theatrical considerations. The witnesses are called for the sensational effects provided by their "tales of horror." ${ }^{27} \mathrm{~K}$-Zetnik's breakdown is an accidental yet consistent illustration of this logic that transforms testimony into a theatrical event that parasitizes the trial.

Arendt writes:

At no time is there anything theatrical in the conduct of the judges.... [J]udge Landau ... is doing his best, his very best to prevent this trial from becoming a show trial under the influence of the prosecutor's love of showmanship. Among the reasons he cannot always succeed is the simple fact that the proceedings happen on a stage before an audience, with the usher's marvelous shout at the beginning of each session producing the effect of the rising curtain. Whoever planned this auditorium ... had a theater in mind .... [C]learly, this courtroom is not a bad place for the show trial David Ben Gurion, Prime Minister of Israel, had in mind when he decided to have Eichamnn kidnapped in Argentina and brought to the district court of Jerusalem to stand trial for his role in "the final solution to the Jewish question."

Yet no matter how consistently the judges shunned the limelight, there they were, seated at the top of the raised platform, facing the audience as from the stage in a play .... [T] he audience was supposed to represent the whole world ... [T] hey were to watch a spectacle as sensational as the Nuremberg Trials, only this time "the tragedy of Jewry as a whole was to be the central concern."

It was precisely the play aspect of the trial that collapsed under the weight of the hair-raising atrocities.

Thus, the trial never became a play, but the show trial Ben

27. Id. at 223. Cf. id. at 8 ("As witness followed witness and horror was piled upon horror, [the audience] sat there and listened in public to stories they would hardly have been able to endure in private."). 
Gurion had had in mind ... did take place. ${ }^{28}$

Most of the witnesses, Arendt narrates, were Israeli citizens who "had been picked from hundreds and hundreds of applicants." ${ }^{29}$ But Arendt is suspicious of witnesses who volunteer. She is allergic to the narcissism she keeps spying both in the legal actors (the chief prosecutor in particular) and in the witnesses whom she suspects of seeking or being complacent with the elements of spectacle that parasitize and compromise the trial. K-Zetnik is for her a case in point. The narrative of his collapse becomes, in Arendt's hands, not an emotional account of human testimonial pathos but a didactic tale that illustrates ironically what accidents can happen when a witness is, quite paradoxically, too eager to appear. It is thus with her most sarcastic, her most undercutting, and most funny style that Arendt will approach this testimony.

How much wiser it would have been to resist these pressures altogether... and to seek out those who had not volunteered! As though to prove the point, the prosecution called upon a writer, well known on both sides of the Atlantic under the name K-Zetnik ... as the author of several books on Auschwitz which dealt with brothels, homosexuals, and other "human interest stories." He started off, as he had done at many of his public appearances, with an explanation of his adopted name.... He continued with a little excursion into astrology: the star "influencing our fate in the same way as the star of ashes at Auschwitz is there facing our planet, radiating toward our planet." And when he had arrived at "the unnatural power above Nature" which had sustained him thus far, and now, for the first time, paused to catch his breath, even Mr. Hausner felt that something had to be done about this "testimony," and, very timidly, very politely, interrupted: "Could I perhaps put a few questions to you if you will consent?" Whereupon the presiding judge saw his chance as well: "Mr. Dinoor, please, please listen to Mr. Hausner and to me." In response, the disappointed witness, probably deeply wounded, fainted and answered no more questions. ${ }^{30}$

"[E]ven Mr. Hausner felt that something had to be done about this "testimony." For Arendt, this is a "testimony" only in quotation marks. It is an aberration of a testimony. Arendt's derision is, however, not directed personally at K-Zetnik but derives from an impersonal black-humorous perception of the ludicrous, hilarious way in which the courtroom as a whole could be mistaken, at this legally surprising moment, for a theater of the absurd. The buffoonery comes from the situation, not from the people. The farcical or comic element derives from the discrepancy and

29. Id. at 223 .

30. Id. at 223-24. 
from the total incommensurability between the two dimensions that the testimony inadvertently brings into dialogue: the natural and the supernatural, the rationality and discipline of courtroom protocols and the irruption of irrationality through a delirious rambling or what Arendt calls an "astrological excursion" (the witness's voyage into "other planets"). ${ }^{31} \mathrm{I}$ would argue differently than Arendt that the courtroom in its very legal essence here flirts with madness and with nonsense. For some, this courtroom drama and the suffering it unfolds both in the past and in the present of the courtroom constitute a tragedy, a shock. For Arendt, this is a comedy. Pain is translated into laughter. If this is theater, sometimes potentially sublime or tragic, it is a Brechtian theater. Keeping her distance is crucial for Arendt. The ludicrous example of K-Zetnik's fainting and his default as a witness illustrates, for Arendt, not the proximity uncannily revealed between madness and reason, not the profound pathos of a cognitive abyss abruptly opened up inside the courtroom and materialized in the unconscious body of the witness, but the folly of the prosecution in both its disrespect for legal relevance and in its narcissistic and misguided predilection for witnesses of prominence. This double folly of the prosecution gets both its poetic justice and its comic punishment when its own witness faints outside the witness stand and inadvertently becomes an inert, hostile witness who "answers no more questions." 32

\section{Evidentiary Misunderstandings}

Looking at the facts, Arendt's fierce irony ironically is based on two erroneous assumptions:

1) Contrary to what Arendt presumes, Dinoor did not volunteer to share his "tale of horror" on the witness stand but instead was an involuntary and reluctant witness. As a writer, he had always shunned public appearances as a matter of principle. Consequently, he had at first refused to testify. The chief prosecutor pressured Dinoor to obtain his reluctant consent to appear before the court.

2) Among the trial's testimonies, Arendt depicts K-Zetnik's as the testimony that is self-evidently the most crazily remote from facts. ${ }^{33}$ She

31. Id.

32. Id. at 224 .

33. Arendt refers to the common sense of the situation. But as Robert Ferguson notes, "common sense, as anthropologists have begun to show, is basically a culturally constructed use of experience to claim self evidence; it is neither more nor less than "an authoritative story' made out of the familiar." Robert Ferguson, Untold Stories in the Law, in LAW's STORIES: NARRATIVE AND RHETORIC IN THE LAW 87 (Peter Brooks \& Paul Gewirtz eds., 1996) (emphasis added) (referring to CLIFFORD GEERTZ, Commonsense as a Cultural System, in GEERTZ, LOCAL KNOWLEDGE: FURTHER ESSAYS IN 
thus regards this testimony as the most grotesque and hyperbolic illustration of "the right of the witnesses to be irrelevant," 34 and presumes it could not possibly bear any legal relevance to Eichmann's case. What Arendt does not know and does not suspect is that Dinoor was one of the very few survivors known to have actually met Eichmann at Auschwitz. ${ }^{35}$ Had he been able to complete his testimony, he would have turned out to be a material eyewitness.

Yet what K-Zetnik wants is not to prove, but to transmit. The language of the lawyer and that of the artist meet across the witness stand only to concretize within the trial their misunderstanding and their missed encounter. ${ }^{36}$

"When the prosecutor invited me to come and testify at the Eichmann trial," writes K-Zetnik more than twenty years after the trial,

I begged him to release me of this testimony. The prosecutor then said to me: Mr. Dinoor, this is a trial whose protocol must put on record testimony proving that there was a place named Auschwitz and what happened there. The mere sound of these words made me sick to my stomach, and I said: Sir, describing Auschwitz is beyond me! Hearing me, his staff eyed me with suspicion. You, the man who wrote these books, you expect us to believe you can't explain to the

INTERPRETIVE ANTHROPOLOGY, 73 (1983)).

34. ARENDT, supra note 10 , at 225 .

35. In the documentary of ABC News THE TRIAL OF ADOLPH EICHMANN, supra note 7, Hausner's wife corroborates this fact, explaining why her husband chose to call K-Zetnik despite the reluctance of the writer.

36. I analyze this missed encounter and this professional misunderstanding for different purposes than simply to contrast (as does for instance Mark Osiel) disciplinary differences. Osiel writes:

It is this confessedly subjective experience-irrelevant to criminal law-that oral historians have only recently sought to explore. In this respect, scholars have perceived the need to overcome what they perceive as a 'legal' concern with the factual accuracy of personal testimony in order to apprehend its historical significance. That is, these scholars try to grasp the meaning of the period's most traumatic events through the continuing memory of those who lived through its trauma. One such scholar writes:

Testimonies are often labeled as "subjective" or "biased" in the legal proceedings concerning war crimes. The lawyers of war criminals have asked the most impertinent questions of people trying to find words for a shattered memory that did not fit into any language.... They demand precise statements of facts... A lawyer's case is after all merely another kind of story.

It is not the task of oral historians to give the kind of evidence required in a court of law. . [Some historians attempt to uncover] the ways in which suffering is remembered and influences all other memory... One is dealing with an effort to create a new kind of history that cannot be used as legal evidence since it explicitly records subjective experience."

Selma Leydersdorff, A Shattered Silence: The Life Stories of Survivors of the Jewish Proletariat at Amsterdam, in MEMORY AND TOTALITARIANISM 145, 147-48 (Luisa Passerini ed., 1992), quoted and surveyed in OSIEL, supra note 3, at 103-04.

My own interest is not in contrasting the historical recording of trauma with that of the law, but on the contrary in exploring and in analyzing ways in which collective trauma is apprehended (and misapprehended) by the law, and ways in which the very limits of the law in its encounter (or its missed encounter) with the phenomenon of trauma reveal precisely cultural aspects of its traumatic meaning. 
judges what Auschwitz was? I fell silent. How could I tell them that I am consumed by the search for the word that will express the look in the eyes of those who headed toward the crematorium, when they passed me with their gaze inside my eyes? The prosecutor was not convinced, and I appeared at the Eichmann trial. Then came the judges' first question about Auschwitz and no sooner did I squeeze out a few miserable sentences than I dropped to the floor and was hospitalized half paralyzed and disfigured in my face. ${ }^{37}$

\section{Trauma and the Language of the Law}

"“Mr. Dinoor," goes Arendt's contrapuntal narrative, “"please, please listen to Mr. Hausner and to me.' In response, the disappointed witness, probably deeply wounded, fainted and answered no more questions." 38

Follows Arendt's serious commentary on her own sarcastic and laughingly didactic tale:

This, to be sure, was an exception, but if it was an exception that proved the rule of normality, it did not prove the rule of simplicity or of ability to tell a story, let alone of the rare capacity for distinguishing between things that had happened to the storyteller more than sixteen, and sometimes twenty, years ago, and what he had read and heard and imagined in the meantime. ${ }^{39}$

For these very reasons, Nuremberg at the war's end excluded living witnesses and limited the evidence to documents, opting for a case of legal invulnerability that only the non-human and non-living paper evidence could guarantee. "The documents," said Jackson, "could not be accused of partiality, forgetfulness, or invention. . . . Witnesses," on the other hand, "many of them persecuted and hostile to the Nazis, would always be chargeable with bias, faulty recollection, and even perjury." 40 In a similar vein, Arendt disqualifies K-Zetnik as a witness because his testimony fails to meet legal criteria and fails to be contained by the authority of the restrictive safeguards of the legal rules. In Jackson's spirit, out of concern for the law as representative of culture and as the arbiter of truth in history, Arendt excludes K-Zetnik's discourse because it stands for the contamination between facts and fiction - for the confusion and the interpenetration between law and literature - that the law in principle cannot accept and has to resolutely, rigidly rule out.

By legal standards, K-Zetnik represents for Arendt a communicative failure. I will argue here that Arendt in her turn represents, in more than

37. KA-TZETNIK, supra note 12, at 32 (translation modified by author according to Hebrew original, supra note 12 , at 50 ).

38. ARENDT, supra note 10 , at 224.

39. Id.

40. Jackson, supra note 2 , at $\mathrm{xxxv-xxxvi.}$ 
one sense, in her stance toward K-Zetnik, the limits of the law in its encounter with the phenomenon of trauma. ${ }^{41}$

I would like now to contrast Arendt's interpretation of K-Zetnik's legal failure with my own reading of this courtroom scene.

IV

\section{Intrusions}

What Arendt's irony illuminates is how the law is used as a straightjacket to tame history as madness.

Arendt's sarcastically positivistic vision of K-Zetnik's failure makes a positivistic recourse to a summarily explanatory psychological vocabulary, through which the legal vision overrides (and Arendt condescendingly dismisses) the witness's (narcissistic) subjectivity. "In response, the disappointed witness, probably deeply wounded, fainted and answered no more questions." ${ }^{, 42}$

Against this simplifying psychological vocabulary, I will propose to use a psychoanalytic one informed by jurisprudential trauma theory. ${ }^{43} \mathrm{I}$ will combine thereby a psychoanalytic with a philosophical and legal reading of this courtroom scene.

Out of the witness stand falls, in my vision, not a "disappointed witness," but a terrified one. The witness is not "deeply wounded," but is retraumatized. The trial reenacts the trauma.

I have argued elsewhere that the law is, so to speak, professionally blind to its constitutive and structural relation to both private and collective, cultural trauma, and that its "forms of judicial blindness" take shape wherever the structure of the trauma unwittingly takes over the structure of a trial and wherever the legal institution, unawares, triggers a legal repetition of the trauma that it puts on trial or attempts to cure. ${ }^{44}$ In KZetnik's case, this happens punctually.

When the judge admonishes Dinoor from the authoritarian position of the bench, coercing him into a legal mode of discourse and demanding his cooperation as a witness, $\mathrm{K}$-Zetnik undergoes severe traumatic shock in re-experiencing the same terror and panic that dumbfounded him each

41. On the relation between trauma and the law, see Shoshana Felman, Forms of Judicial Blindness: Traumatic Narratives and Legal Repetitions, in MEMORY, HISTORY AND THE LAW 25 (Austin Sarat \& Thomas R. Kearns eds., 1999).

42. ARENDT, supra note 10 , at 224.

43. For my own "jurisprudential trauma theory," see Felman, supra note 41. For trauma theory in general and its importance in the humanities, see, e.g., Bessel A. Van der Kolk \& Onno Van der Hart, The Intrusive Past: The Flexibility of Memory and the Engraving of Trauma, in TRAUMA: EXPLORATIONS IN MEMORY 158 (Cathy Caruth ed., 1995); CATHY CARUTH, UNCLAIMED EXPERIENCE: TRAUMA, NARRATIVE AND HISTORY (1996).

44. See Felman, supra note 41 , at 25-93. 
time when, as an inmate, he was suddenly confronted by the inexorable Nazi authorities of Auschwitz. The judge's words are heard not as an utterance originating from the present of the courtroom situation, but as a censure uttered from within "the other planet," as an intrusive threat articulated right out of the violence of the traumatic scene that is replaying in K-Zetnik's mind ${ }^{45}$ The call to order by the judge urging the witness to obey-strictly to answer questions and to follow legal rules-impacts the witness physically as an invasive call to order by an SS officer. Once more, the imposition of a heartless and unbending rule of order violently robs him of his words and, in reducing him to silence, once more threatens to annihilate him, to erase his essence as a human witness. Panicked, KZetnik loses consciousness. ${ }^{46} \mathrm{He}$ will later write about his unrelenting Auschwitz nightmares:

In a trembling I lift my eyes to see the face of God in its letters, and see in front of me the face of an SS man. ${ }^{47}$

I grow terrified. ... The rules here are invisible. ... No telling what's permitted and what's prohibited. ${ }^{48}$

I was seized by fear and trembling. I am crying of dread. I want to hide my face and not be seen. But there is no escape from Auschwitz. There is no hiding place in Auschwitz. ${ }^{49}$

\section{Between Life and Death: Frontier Evidence}

Prior to his fainting spell, at the point where the prosecutor interrupts him, K-Zetnik tries to define Auschwitz by re-envisaging the terrifying moment of Selection, of repeated weekly separation between inmates chosen for an imminent extermination and inmates arbitrarily selected for life. This moment is ungraspable, the witness tries to say:

And the inhabitants of that planet had no names. They had neither parents nor children... They did not live, nor did they die, in

45. On the phenomenon of intrusive memory and of traumatic repetition prevalent in the aftermath of trauma, see for instance, Van der Kolk \& Van der Hart, supra note 43.

46. This terrified collapse is at the same time an improbable act of resistance, a gesture of defiance of the court and of its ruling.

47. KA-TZETNIK, supra note 12 , at 9 (translation modified by author according to Hebrew original, supra note 12 , at 24 ). I will use this literary, autobiographical narrative written subsequently by K-Zetnik to describe his psychiatric therapy from his recurrent Auschwitz nightmares, to retrospectively illuminate the drama of the courtroom scene.

48. Id. at 95 (translation modified by author according to Hebrew original, supra note 12, at 107).

49. Id. at 40 (translation modified by author according to Hebrew original, supra note 12, at 57). Compare: "But I have no choice. I am unable to answer questions. In general I cannot sustain interrogation. This is a trauma whose origin is in the torture cellar of the Gestapo in Katowice." Id. at 20. 
accordance with the laws of this world. Their names were the numbers. ... They left me, they kept leaving me, left ... for close to two years they left me and always left me behind ... I see them, they are watching me, I see them.$^{50}$

What K-Zetnik keeps reliving of the death camp is the moment of departure, the last gaze of the departed, the exchange of looks between the dying and the living at the very moment in which life and death are separating but are still tied up together and can for the last time see each other eye to eye.

"Even those who were there don't know Auschwitz," writes K-Zetnik in a later memoir:

Not even someone who was there for two long years as I was. For Auschwitz is another planet, whereas we humankind, occupants of the planet Earth, we have no key to decipher the code-name Auschwitz. How could I dare defile the look in the eyes of those who head toward the crematorium? They passed me, they knew where they were going, and I knew where they were going. Their eyes are looking at me and my eyes are looking at them, the eyes of the going in the eyes of the remaining, under silent skies above the silent earth. Only that look in the eyes and the last silence. eyes. ${ }^{51}$

For two years they passed me and their look was inside my A Community of Death, or Giving Voice to What Cannot Be Said

In constantly reliving through the moment of departure the repeated separation between life and death, what K-Zetnik testifies to is, however, not the separation or the difference between life and death but on the contrary their interpenetration, their ultimate resemblance. On the witness stand, he keeps reliving his connection to the dead, his bond to the exterminated. His loyalty to them is symbolized by his adopted name KZetnik, with which he signs, he says, the stories that in fact are theirs:

Since then this name testifies on all my books....

I am a man! . . A man who wants to live!

"You have forgotten to write your name on the manuscript ...."

50. 3 ProceEdings, supra note 11 , at 1237.

51. Id. at $\mathrm{x}$-xi (translation modified by author according to Hebrew original, supra note 12, at 89). 
"The nameless, they themselves! The anonymous! Write their name: K-Zetnik." 52

How could I explain that it was not me who wrote the book; they who went to the crematorium as anonymous, they wrote the book! They, the anonymous narrators. ... For two years they passed before me on their way to the crematorium and left me behind. ${ }^{53}$

All of them are now buried in me and continue to live in me. I made an oath to them to be their voice, and when I got out of Auschwitz they went with me, they and the silent blocks, and the silent crematorium, and the silent horizons, and the mountain of ashes. ${ }^{54}$

In a way K-Zetnik on the witness stand is not alone. He is accompanied by those who left him but who live within him. "I made an oath to them to be their voice." The writer K-Zetnik therefore could symbolically be viewed as the most central witness to the trial's announced project to give voice to the six million dead. K-Zetnik's testimony and his literary project pick up on the prosecutor's legal project.

When I stand before you, Judges of Israel, in this court [-the prosecutor said in his opening address- - I do not stand alone. With me... stand six million prosecutors. But alas, they cannot rise to level the finger of accusation in the direction of the glass dock and cry out J'accuse against the man who sits there. For their ashes are piled in the hills of Auschwitz...Their blood cries to Heaven, but their voice cannot be heard. Thus it falls to me to be their mouthpiece and to deliver the awesome indictment in their name. ${ }^{55}$

\section{Between Two Names}

Because he is in turn speaking for the dead, K-Zetnik must remain, like them, anonymous and nameless. He must testify, that is, under the name K-Zetnik. ${ }^{56}$ His memory of Auschwitz is the oblivion of his name. But in a court of law, a witness cannot remain nameless, and cannot testify

52. Id. at 16 (translation modified by author according to Hebrew original, supra note 12 , at 32 ).

53. Id. at $\mathrm{x}$-xi (translation modified by author according to Hebrew original, supra note 12 , at 33 )

54. Id. at 18 (translation modified by author according to Hebrew original, supra note 12, at 34 ).

55. Criminal Case 40/61 (Jerusalem), Attorney General v. Eichmann, translated in 1 THE TRIAL of ADOLPH EICHMANN, RECORd OF PROCEEDINGS IN THE District COURT OF JERUSALEM, Session No. 6, Apr. 17, 1967, Jerusalem 1962, at 62 [hereinafter 1 PROCEEDINGS], quoted in HAUSNER, supra note 4, at 323-24; ARENDT, supra note 10, at 260.

56. Under this name with which he signs his literary work and which materializes his oath to the dead, Dinoor continues not just to remember those who left him, but also, as a writer, to give literary voice to their last look and to their final silence. 
anonymously. A witness is accountable precisely to his legal, given name.

"Mr. Dinoor, please, please listen to Mr. Hausner and to me," 57 says the presiding judge impatiently, putting an end to the account that the witness gives of his adopted name.

K-Zetnik faints because he cannot be interpellated at this moment by his legal name, Dinoor: the dead still claim him as their witness, as K-Zetnik who belongs to them and is still one of them. The court reclaims him as its witness, as Dinoor. He cannot bridge the gap between the two names and the two claims. He plunges into the abyss between the different planets. On the frontier between the living and the dead, between the present and the past, he falls as though he were himself a corpse.

\section{V}

\section{Unmastered Past}

Having no interest in socio-psychological or psychoanalytical phenomena, Arendt has neither a profound insight into nor an interest in trauma. She has an interest, however, in its legal remedy-in the trial as a means to overcome and to subdue a traumatic past. But K-Zetnik does not seize his legal chance to overcome the trauma on the witness stand. He is rather once more overcome by it. What is worse, he makes a spectacle of his scandalous collapse within the legal forum. K-Zetnik thus defeats the purpose of the law, which is precisely to translate the trauma into consciousness. He loses consciousness and loses his self-mastery, whereas the purpose of the law is on the contrary to get under control and to regain a conscious mastery over the traumatic nightmare of a history whose impact, Arendt recognizes in her non-pathetic, understated style, continues to have repercussions in the world's consciousness and thus remains with all of us precisely as the world's, Israel's as well as Germany's "unmastered past." 58

At the heart of the "unmastered past," the trial tries to master an abyss. ${ }^{59}$

57. THE TRIAL OF ADOLPH EICHMANN, supra note 7 (author's literal transcription) (emphasis added).

58. "It now appeared," writes Arendt,

that the era of the Hitler regime, with its gigantic, unprecedented crimes, constituted an

"unmastered past" not only for the German people or the Jews all over the world, but for the rest of the world, which had not forgotten this great catastrophe in the heart of Europe either, and had also been unable to come to terms with it. Moreover-and this was perhaps less expected-general moral questions, with all their intricacies and modern complexities, which I would never have suspected would haunt men's minds today and weigh heavily on their hearts, stood suddenly in the foreground of public concern.

ARENDT, supra note 10, at 283 (emphasis added).

59. On the relation between trials and historical and cultural abysses, see Felman, supra note 41 , at 69-83. 


\section{Trials and Abysses}

K-Zetnik's loss of consciousness materializes in the courtroom what the trial cannot master: at once an abyss of trauma and an epistemological abyss, a cognitive rupture that Arendt, unrelatedly, will theorize and underscore in her political and philosophical account of the Nazi genocide ${ }^{60}$ Arendt in turn experienced this epistemological abyss when the news of Auschwitz reached her for the first time as a shock that could not be assimilated. "What was decisive," Arendt confides to Gunter Gaus in a German radio interview in 1964,

was the day we learnt about Auschwitz. That was in 1943. And at first we didn't believe it ... because militarily it was unnecessary and uncalled for. My husband ... said don't be gullible, don't take these stories at face value. They can't go that far! And then a half-year later we believed it after all, because we had the proof. That was the real shock. Before that we said: Well one has enemies. That is entirely natural. Why shouldn't a people have enemies? But this was different. It was really as if an abyss had opened. ${ }^{61}$

But despite the shock, despite the cognitive rupture and the epistemological gap in history and in historical perception, Arendt's life consists in crossing the abyss and overstepping it, beyond the rupture it has left. It later seems to Arendt, as she says to Gunter Gaus, that "there should be a basis for communication precisely in the abyss of Auschwitz." ${ }^{\prime 2}$ The law provides a forum and a language for such

60. This abyss, this epistemological rupture, is what the Eichmann trial and its "monumental history" (at once the prosecution's case and the text of the judgment) precisely fails to perceive in Arendt's eyes. "I have insisted," Arendt writes,

on ... how little Israel, and the Jewish people in general, was prepared to recognize, in the crimes that Eichmann was accused of, an unprecedented crime.... In the eyes of the Jews, thinking exclusively in terms of their own history, the catastrophe that had befallen them under Hitler, in which a third of the people perished, appeared not as the most recent of crimes, the unprecedented crime of genocide, but on the contrary, as the oldest crime they knew and remembered. This misunderstanding... is actually at the root of all the failures and the shortcomings of the Jerusalem trial. None of the participants ever arrived at a clear understanding of the actual horror of Auschwitz, which is of a different nature from all the atrocities of the past... . Politically and legally... these were "crimes" different not only in degree of seriousness but in essence.

ARENDT, supra note 10, at 267.

Compare Arendt's insistence in her 1946 letter to Jaspers on the abyss that, henceforth inhabiting both guilt and innocence, explodes the tool of law in bursting open all legal frameworks: "The Nazi crimes, it seems to me, explode the limits of the law. . . . this guilt, in contrast to all criminal guilt, oversteps and shatters any and all legal systems. That is the reason why the Nazis in Nuremberg are so smug .... and just as inhuman as their guilt is the innocence of the victims .... This is the abyss that opened up before us as early as 1933 . . . and into which we have finally stumbled. I don't know how we will ever get out of it." Letter from Arendt to Japsers, supra note 20 (emphasis added).

61. HANNAH ARENDT, "What Remains?" The Language Remains; A Conversation with Gunther Gaus, in ESSAYS IN UNDERSTANDING, 1930-1954, at 13-14, (Jerome Kottn ed., 1994).

62. Id. at 14 . 
communication.

I would argue that the Eichmann trial is, for Arendt, quite precisely what she calls "the basis for communication" in and over the abyss of Auschwitz. But K-Zetnik's plunge into a coma interrupts the process of communication painstakingly established by the law. K-Zetnik has remained too close to the reality and to the shock of the event, perhaps too close for Arendt's comfort. He is still a captive of the planet of the ashes. $\mathrm{He}$ is still in the Holocaust, still on the brink of the abyss, which he unwittingly reopens in the courtroom when the law has barely started to construct its legal bridge.

The law requires that the witness should be able to narrate a story in the past, to recount an event in the past tense. K-Zetnik is unable to regard the Holocaust as past event but must relive it in the present, through the infinite traumatic repetition of a past that is not past, that has no closure and from which no distance can be taken.

Law, on the contrary, requires and provides distance from the Holocaust. Its inquiry and judgment are contingent on a separation between past and present. Law requires and brings closure and totalization of the evidence and of its meaning. This is why K-Zetnik's testimony, which defies at once legal reduction and legal closure, must remain unrealized, unfinished.

\section{PART TWO: EVIDENCE IN LAW AND EVIDENCE IN ART}

VI

\section{Between Law and Art}

In 1964, a leading avant-garde literary critic in America, Susan Sontag, in a discussion of a German literary work about the role played by the Pope during the Holocaust, surprisingly and quite provocatively argued that the Eichmann trial was "the most interesting and moving work of art of the past ten years." 63

63. Susan Sontag, Reflections on The Deputy, in THE STORM OVER THE DEPUTY 18 (Eric Bentley ed., 1964). This comment was, of course, an utterly astonishing remark whose value lay in the surprise that it reserved, in its unsettling power with respect to any simple-minded or reductive legalistic understanding of the trial. Provocatively, Sontag argued that there was a dimension in the trial that was excessive to its legal definition. She called this dimension "art," because she felt the trial left an impact on the audience that was, in its strength and depth, comparable to the expressive power of a work of art. The trial moved her and existentially and philosophically engaged her. Sontag insisted therefore that the trial had a literary meaning in addition to its legal meaning ${ }_{2}$ and that this extra-legal meaning was somehow utterly important for a full grasp of what was at stake in this event of law. The value of Sontag's interpretation lies, in my eyes, not in its axiomatic categorization of the trial as a work of art (a categorization I cannot accept), but in the power of this unexpected categorization to destabilize the category of the legal and to open it for further thought and for a larger cultural interrogation. 
We live in a time in which tragedy is not an art form but a form of history. Dramatists no longer write tragedies. But we do have works of art (not always recognized as such) which attempt to resolve the great historical tragedies of our time.... If then the supreme tragic event of modern times is the murder of six million Jews, the most interesting and moving work of art of the past ten years is the trial of Adolf Eichmann in Jerusalem in $1961{ }^{64}$

I do not believe, for my part, that the Eichmann trial-or any trial-can be reduced to, or subsumed in, the performance or the drama of a work of art. There is at least one crucial difference between an event of law and an event of art, no matter how dramatic they both are: $A$ work of art cannot sentence to death. A trial, unlike art, is grounded in the sanctioned legal violence it has the power (and sometimes the duty) to enact. ${ }^{65}$

While it cannot be accepted at face value, Sontag's paradoxical remark about the Eichmann trial is nevertheless illuminating, not as a comment about trials, but as an observation about art's relation to (juridical) reality. While the Eichmann trial can under no circumstances be regarded as a work of art, works of art have come today to imitate, to replicate or to mimic the legal structures of the Eichmann trial.

The strongest and most eloquent example of this trend (that reached its climax decades after Sontag's article) can be seen in the film Shoah by Claude Lanzmann, a work of art made of reality whose legal, testimonial format is informed (and perhaps inspired) by the Eichmann trial ${ }^{66}$ and of which it could indeed be said, in Sontag's words, that it is "the most interesting and moving work of art of the past years." ${ }^{67}$

64. Id. at 118-19. Art, says Sontag, no longer stands in opposition to reality: While twentiethcentury reality becomes more and more hallucinated, more and more divorced from what we used to call reality, art moves closer to reality than it ever was before, and mixes in with its jurisprudential gestures. Art no longer is a statement: it is an intervention in a conflict, an action, a commitment, an engagement. It is politicized and de-aestheticized. A "work of art" no longer is aesthetics: It is politics. See id.

65. See ROBERT COVER, Violence and the Word, in NARRATIVE, VIOLENCE AND THE LAW: THE ESSAYS OF ROBERT COVER 203 (Martha Minow, Michael Ryan \& Austin Sarat eds., 1995).

66. Shoah borrows some of its main witnesses from the Eichmann trial. The most striking example is that of Simon Srebnik, whose extraordinary testimony was first heard during the proceedings of the Eichmann trial. Compare Session No. 66, in 3 PROCEEDINGS, supra note 11, at 1197-1201, with Shoah's extraordinarily moving opening scene, in SHOAH, THE COMPLETE TEXT OF THE FILM BY CLAUDE LANZMANN (1985).

67. Like the Eichmann trial, Lanzmann's film puts in evidence before the audience a fact-finding process whose goal is-like that of the legal process-to elicit truth and to prohibit its evasions. Lanzmann borrows his procedures-his techniques of cross-examination and of detailed, concrete interrogation-from the legal model of a trial. Like the Eichmann trial, Shoah hears testimonies in a multiplicity of languages and uses an interpreter to simultaneously translate them into the language of its legal process. And like the Eichmann trial, the film wishes not only to prove but to transmit. "My problem,' Lanzmann says, 'was to transmit. To do that one cannot allow oneself to be overwhelmed with emotion. You must remain detached.... I tried rather to reach people through their intelligence." Shoshana Felman, The Return of the Voice, in SHOSHANA FELMAN \& DORI LAUB, TESTIMONY: CRISES OF WITNESSING IN HISTORY, PSYCHOANALYSIS AND LITERATURE 204, 239 (1992) (quoting Claude Lanzmann) (citation omitted). For a more elaborate study of the film Shoah, 
I speak here of Shoah as emblematic of art after the Holocaust and as paradigmatic of the work of art of our times. I argue that the Eichmann trial is the complementary event (the legal correlative) of the contemporary process of art's invasion by the structures of the trial and of its transformation into testimony, a process by which writers like K-Zetnik (like Elie Wiesel, Celan, Camus and others) have precisely vowed to make of art itself a witness, to present, that is, historical and legal evidence by means of art. What, then, is the difference between law and art when both are underwritten by the legal process and when both vow to pursue reality? "Reality," says Arendt, "is different from, and more than, the totality of facts and events, which anyhow is unascertainable. Who says what is ... always tells a story."68 In Arendt's words, I argue that law's story focuses on ascertaining the totality of facts and events. Art's story focuses on what is different from, and more than, that totality. I argue that the breakdown of the witness in the Eichmann trial was (unwittingly) at once part of the totality of facts and part of what was different from, and more than, that totality. In that sense, it was inadvertently law's story and art's story at the same time. "The truth" says Lanzmann, "kills the possibility of fiction." ${ }^{69}$ In the same way that art is today transpierced, invaded by the language and the structures of the trial, the Eichmann trial-through K-Zetnik's court appearance-was transpierced, invaded by the artist's language, by the artist's testimony and by the artist's astonishing collapse.

The artist's language cannot relegate traumatic suffering to the past. "The worst moral and artistic crime that can be committed in producing a work dedicated to the Holocaust," says Lanzmann, "is to consider the Holocaust as past. Either the Holocaust is legend or it is present: in no case is it a memory. A film devoted to the Holocaust ... can only be an investigation into the present of the Holocaust or at least into a past whose scars are still so freshly and vividly inscribed in certain places and in the consciences of some people that it reveals itself in a hallucinated timelessness. ${ }^{70}$ In a similar way, K-Zetnik does not treat the Holocaust as past but lives it as a present that endlessly repeats itself in a hallucinated timelessness. The hallucinated timelessness-the time of traumatic repetition and the time of art-is the precise time of K-Zetnik's legal testimony. But legal temporality cannot admit, cannot include, cannot acknowledge timelessness except as rupture of the legal frame. K-Zetnik's court appearance marks, thus, an invasion of the trial and of legal

\footnotetext{
see id.

68. ARENDT, Truth and Politics, in BETWEEN PAST AND FUTURE 227, 261 (Penguin Books 1993) (1961).

69. Deborah Jerome, Resurrecting Horror: The Man Behind Shoah, RECORD, Oct. 25, 1985 (interviewing Claude Lanzmann).

70. Claude Lanzmann, From the Holocaust to "Holocaust," in DISSENT, Spring 1981, at 194 (emphasis added).
} 
temporality by the endless, timeless temporality of art.

Law is a language of abbreviation, of limitation and totalization. Art is a language of infinity and of the irreducibility of fragments, a language of embodiment, of incarnation and of embodied incantation or of endless rhythmic repetition. Because it is by definition a discipline of limits, law distances the Holocaust; art brings it closer. The function of the judgment in the Eichmann trial was paradoxically to totalize and distance the event: The trial made a past out of the Holocaust. ${ }^{71}$ And yet, within the courtroom, in the figure of K-Zetnik, the Holocaust returned as a ghost or as an incarnated, living present.

K-Zetnik's discourse in the trial has remained unfinished and, like art, interminable. In the courtroom, its lapse into interminability-into unconsciousness and silence-was paradoxically a physical reminder of the real, a physical reminder of a bodily reality that fractured the totality of facts sought by the law. But the testimonial power of this real, of this irreducible bodily presence of the witness, lay precisely in the pathos-in the crying power- of its legal muteness.

"But what can I do when I'm struck mute?" K-Zetnik will write almost thirty years after the Eichmann trial, in trying to explain at once the legal failure of his testimony and the very principle of interminability and inexhaustibility of his continued testimonial art:

But what can I do when I'm struck mute? I have neither word nor name for it all. Genesis says: "And Adam gave names..." When God finished creating the earth and everything upon it, Adam was asked to give names to all that God had created. Till 1942 there was no Auschwitz in existence. For Auschwitz there is no name other than Auschwitz. My heart will be ripped to pieces if I say, "In Auschwitz they burned people alive!" Or "In Auschwitz people died of starvation." But that is not Auschwitz. People have died of starvation before, and people did burn alive before. But that is not Auschwitz. What, then, is Auschwitz? I have no words to express it; I don't have a name for it. Auschwitz is a primal phenomenon. I don't have the key to unlock it. But don't the tears of the mute speak his anguish? And don't his screams cry his distress? Don't his bulging eyes reveal the horror? I am that mute. ${ }^{72}$

Muteness in a courtroom is normally negative or void, devoid of legal meaning. Muteness in art, however, can be fraught with meaning. It is out

71. On the historicizing role of the judges and more generally on the relation between law and history, see the remarkable analysis of Michal Shaked, Hahistoriah Beveit Hamishpat Uveit Hamishpat Bahistoria. Piskei Hadin Bemishpat Kastner Vehanarrativim Shel Hazikaron [History in Court and the Court in History: The Opinions in the Kastner Trial and the Narratives of Memory], 20 ALPAIM 36 (2000).

72. KA-TZETNIK, supra note 12, at 31-32 (translation modified by author according to K-ZETNIK, supra note 12 , at 49 ). 
of its muteness that K-Zetnik's writing in this passage speaks. It is out of its silence that his testimonial art derives its literary power. Art is what makes silence speak.

I would argue that it was precisely through K-Zetnik's legal muteness that the trial inadvertently gave silence a transmitting power, andalthough not by intention-managed to transmit the legal meaning of collective trauma with the incremental power of a work of art. Once the trial gave transmissibility to silence, other silences became, within the trial, fraught with meaning. ${ }^{73}$ At the limit of what could be legally grasped, something of the order of K-Zetnik's mute cry-something of the order of the speechlessness and of the interminability of art-was present in the courtroom as a silent shadow of the trial or as a negative of the proceedings. It was present in the interstices of the law as a ghost inside the house of justice. The poet Haim Gouri noted in his coverage of the trial:

With an unmatched force, the court has managed to restrain the crushing power of the cry that burst out, now as if for the first time, and to transmit it partially into a language of facts and numbers and dates, while letting the remainder of that cry float over the trial like a ghost. $^{74}$

VII

The Judgment

Unlike K-Zetnik's testimony, the Eichmann trial did have closure. For his crimes against the Jewish people, his war crimes and his crimes against humanity, the judges sentenced Eichmann to "the greatest penalty known to the law." 75 The judgment totalized a statement of the evidence. Like

73. See ARENDT, supra note 10, at 231 ("During the few minutes it took Kovner to tell of the help that had come from a German sergeant, a hush settled over the courtroom; it was as though the crowd had spontaneously decided to observe the usual two minutes of silence in honor of the man named Anton Schmidt.").

There were moments in which even the prosecutors were overcome by silence and, for a minute, could not go on. On these inadvertent moments of silence, compare the retrospective testimony of Justice Gabriel Bach, at the time assistant prosecutor in the Eichmann trial, in the documentary film THE TRIAL OF ADOLF EICHMANN, supra note 7, with HAUSNER, supra note 4, at 324-25:

The story of the extermination in Poland followed, and the wholesale killings by the Einsatzgruppen ... There, I knew, words could not describe the mass shooting of close to a million and four hundred thousand people before open pits. I cut short the address and read, instead, a lullaby composed at the time in the Wilno ghetto... When I finished reading there was silence for a moment. I simply could not go on. Fortunately it was almost 6 p.m., about time for the adjournment of the session. The presiding judge must have realized my predicament; he asked whether this was a convenient place to stop. I nodded thankfully.

74. GoURI, supra note 17, at 244.

75. Reading of the Judgment of the District Court, 5 THE TRIAL OF ADOLF EICHHMANN, RECORD 
Arendt, the judges underscored the fact that their authority of doing justice (and of making justice seen) was contingent on the force of limitation of the law. "The Judgement in the Eichmann case," Arendt reports for once approvingly, "could not have been clearer":

All attempts to widen the range of the trial had to be resisted, because the court "could not allow itself to be enticed into provinces which are outside its sphere... The judicial process [-wrote the judges] has ways of its own, which are laid down by law, and which do not change, whatever the subject of the trial may be." The court, moreover, could not overstep these limits without ending "in complete failure." Not only does it not have at its disposal "the tools required for the investigation of general questions, it speaks with an authority whose very weight depends upon its limitation."76

And yet, even the judges felt the need to point to the fact that there was something in the trial that went beyond their jurisdiction and beyond the jurisdiction of the law. Thus they wrote:

If these be the sufferings of the individual, then the sum total of the suffering of the millions-about a third of the Jewish people, tortured and slaughtered -is certainly beyond human understanding, and who are we to try to give it adequate expression? This is a task for the great writers and poets. Perhaps it is symbolic that even the author who himself went through the hell named Auschwitz, could not stand the ordeal in the witness box and collapsed. ${ }^{77}$

What the judges say is not simply that law and art are two modes of transmission of the Holocaust, two languages in which to translate the incomprehensible into some sort of sense, two modes of coping with collective trauma and of crossing the abyss of a mad and nightmarish history.

The judges recognize that even in the legal mode, within the language of the trial, the collapse of the writer and his breakdown as a witness were endowed with meaning. They further recognize that when the artist lapsed into unconsciousness, a dimension of infinitude and interminability has registered itself within the trial as what was uncontainable by its containment, as what remained untotalizable precisely by and in the law's totalization, within the very legal text of the totalization that constitutes their judgment.

The judgment in the Eichmann trial takes note of the fact that, in the

OF Proceedings IN THE District CouRT OF Jerusalem, Session No. 121 (Dec. 15, 1961), Jerusalem 1964, at 2218 [hereinafter 5 PROCEEDINGS].

76. ARENDT, supra note 10, at 253-54 (emphasis added). "Hence," Arendt concludes, "to the question most commonly asked about the Eichmann trial: What good does it do? there is but one possible answer: It will do justice." Id. at 254.

77. 5 PROCEEDINGS, supra note 75, at 2146 (emphasis added). 
meeting point between law and art with which the courtroom was unwittingly confronted through K-Zetnik's testimony, the law has dialogued with its own limits and has touched upon a boundary of meaning in which sense and senselessness, meaning and madness seriously, historically commingled and could not be told apart. The court acknowledges, however, that this surprising legal moment that unsettled legal norms and threw the courtroom into disarray was a profoundly meaningful and not senseless moment of the trial.

\section{PART THREE: TRAUMATIC NARRATIVES AND LEGAL FRAMES}

VIII

Story and Anti-Story: Between Justice and the Impossibility of Telling

I want now to return to Arendt's story, but to return to Arendt's story differently: to listen not just to her statement, but to her utterance; to seek to understand not only her juridical critique, but her own inadvertent testimony as a writer. I propose to show how Arendt's legal narrative in Eichmann in Jerusalem unwittingly encapsulates not only the reporter's critical account, but also the thinker's own (erased) artistic testimony and the writer's own traumatic narrative. ${ }^{78}$

Like the judges, Arendt views K-Zetnik's fainting as a symbol. ${ }^{79}$ But while for the judges, the writer's collapse encapsulates-within the trial and beyond it -the collapse of language in the face of uncontainable and unintelligible suffering, for Arendt, the writer's collapse encapsulates the legal failure of the trial. While for the judges, the collapse is a dramatization of a failure of expression, for Arendt, the collapse is a dramatization of a failure of narration.

"This," says Arendt, "to be sure, was an exception, but if it was an exception that proved the rule of normality, it did not prove the rule of simplicity or of ability to tell a story." rule of normality, that is, as a symbol of the legal abnormality of the trial as a whole, Arendt faults K-Zetnik for his inability to tell a story, and thus to testify coherently. "Who says what is ... always tells a story, and in this story the particular facts lose their contingency and acquire some

78. In her own turn, Arendt narrates not only the totality of facts, but also what is different from, and more than, that totality. Arendt's encounter with the Eichmann trial in turn partakes not only of law's story but also (mutely, indirectly) of art's story, or more precisely of the way in which law's story in the trial is transpierced, pervaded by the writer's testimony.

79. "Perhaps it is symbolic," said the judges, "that even the author who himself went through the hell named Auschwitz, could not stand the ordeal in the witness box and collapsed." 5 PROCEEDINGS, supra note 75, at 2146; see supra text accompanying note 77.

80. ARENDT, supra note 10 , at 224. 
humanly comprehensible meaning," Arendt will write in "Truth and Politics," ${ }^{11}$ doubtless remembering unconsciously the unforgettable essay called The Storyteller ${ }^{82}$ written by her dead friend Walter Benjamin, whose name she will in 1968-five years after the Eichmann bookredeem from anonymity and namelessness by publishing his work in the United States, but whose lost friendship she will silently mourn all her life as an intimate grievance, a wordless wound, a personal price that she in turn has secretly paid to the Holocaust. ${ }^{83}$ I hear a reference to The

81. "The telling of factual truth comprehends much more than the daily information supplied by journalists . . Reality is different from, and more than, the totality of facts and events which, anyhow, is unascertainable. Who says what is ... always tells a story, and in this story the particular facts lose their contingency and acquire some humanly comprehensible meaning." ARENDT, supra note 68, at 261 .

82. BENJAMIN, supra note 6.

83. The German-Jewish writer Walter Benjamin (1892-1940) was a friend of Arendt's during their exile years in Paris. She admired his works and wanted to help him emigrate to the United States, but he committed suicide during his illegal and aborted escape from France in 1940. In 1942, when she first learns about the existence of the Nazi death camps, Arendt writes "a poem for her dead friend, a farewell and a greeting," entitled simply "W.B.:" "[D]istant voices, sadnesses nearby / Those are the voices and these the dead / whom we have sent as messengers ahead, to lead us into slumber." Quoted in ElizaBETH YOUNG-BRUEHL, HANNAH ARENDT: FOR LOVE OF THE WORLD 162-63 (1982).

The last time Walter Benjamin saw Hannah Arendt in Marseille, he entrusted to her care a collection of manuscripts he hoped she could deliver to the United States. After his death, Arendt travels to the cemetery of Port Bou on the Franco-Spanish border only to discover that her dead friend who was buried there does not even have an individual, named grave. In a letter to Gershom Scholem written on October 21, 1940 (less than a month after Benjamin's death), Arendt describes the shock of her realization that in this cemetery, "the most fantastic ... and beautiful spot" she has ever "seen in [her] life," there is nothing left to bear witness to Benjamin's life and death: "[His grave] was not to be found, his name was not written anywhere." Quoted in GERSHOM SCHOLEM, WALTER BENJAMN: THE STORY OF A FRIENDSHIP 226 (Harry Zohn trans., Jewish Publication Soc'y of Am. 1981) (1975).

In 1968, Arendt redeems Benjamin from namelessness in publishing his manuscripts in the United States. In her Introduction to Benjamin's work, Arendt narrates (and mourns) her friend's absurd, untimely, and tragically ironic (needless) suicide:

On September 26, 1940, Walter Benjamin, who was about to emigrate to America, took his life at the Franco-Spanish border. There were various reasons for this ... nothing drew him to America, where, as he used to say, people would probably find no other use for him than to... exhibit him as "the last European." But the immediate occasion for Benjamin's suicide was an uncommon stroke of bad luck. Through the armistice agreement between Vichy France and the Third Reich, refugees from Hitler's Germany... were in danger of being shipped back to Germany. ... . [T]o save this category of refugees . . . the United States had distributed a certain number of emergency visas through its consulates in unoccupied Europe. Thanks to the efforts of the Institute in New York, Benjamin was among the first to receive such a visa in Marseilles. Also, he quickly obtained a Spanish transit visa to enable him to get to Lisbon and board a ship there. However, he did not have a French exit visa ... which the French government, eager to please the Gestapo, invariably denied the German refugees. In general this presented no great difficulty, since a relatively short and none too arduous road to be covered by foot over the mountains to Port Bou was well known and was not guarded by the French border police. Still, for Benjamin apparently suffering from cardiac condition ... even the shortest walk was a great exertion, and he must have arrived in a state of serious exhaustion. The small group of refugees that he had joined reached the Spanish border town only to learn that Spain had closed the border that same day and that the border officials did not honor visas made out in Marseilles. The refugees were supposed to return to France the next day. During the night Benjamin took his life, whereupon the border officials, upon whom this suicide had made an impression, allowed his companions to proceed to Portugal. A few weeks later the embargo on visas was lifted again. One day earlier Benjamin would have got through without any trouble; one day later the people in Marseilles would have known that for the time being it was impossible to 
Storyteller in the conclusion of Arendt's account of K-Zetnik's testimony: "[I]t did not prove the rule of simplicity or of ability to tell a story." There are several other references in Eichmann in Jerusalem to storytelling and to The Storyteller. ${ }^{85}$ While Benjamin's name is never

pass through Spain. Only on that particular day was the catastrophe possible.

Arendt, Introduction to ILlUMinations, supra note 6, at 5-18; see also Arendt's letter of May 30, 1946 to Gertrude Jaspers, the Jewish wife of the German philosopher (The letter is evoking another mutual dead acquaintance, and the two correspondents' common personal relation to the Jewish problem):

Or perhaps he was just tired and didn't want to move on again, didn't want to face a totally alien world, a totally alien language, and the inevitable poverty, which so often, particularly at first, comes close to total destitution. This exhaustion, which often went along with the reluctance to make a big fuss, to summon so much concentration for the sake of this little bit of life, that was surely the biggest danger we all faced. And it was the death of our best friend in Paris, Walter Benjamin, who committed suicide in October 1940 on the Spanish border with an American visa in his pocket. This atmosphere of sauve qui peut at the time was dreadful, and suicide was the only noble gesture, if you even cared enough to want to perish nobly. ... What you wrote about "our" problem moved me very much. ... and today that means our dead.

Letter from Arendt to Gertrude Jaspers (May 30, 1946), in CORRESPONDENCE supra note 20, at 40-41 (emphasis added).

84. ARENDT, supra note 10 , at 224.

85. There is another witness who, in contrast to K-Zetnik, did prove the ability to tell a story. His name is Zyndel Grynszpan, and the story he narrates is that of his forced deportation, at the beginning of the war, from Germany to Poland. He is in Arendt's eyes the ideal storyteller-the ideal witnessalthough no other witness in the trial can live up to his example. His plainly factual and chronologically coherent narrative stands in contrast to the disjointed account of K-Zetnik. "Now he had come to tell his story," Arendt writes, "carefully answering questions put to him by the prosecutor; he spoke clearly and firmly, without embroidery, using a minimum of words." Id. at 228 (emphasis added). Compare Benjamin's similar stylistic preference in The Storyteller:

There is nothing [writes Benjamin] that commends a story to memory more effectively than the chaste compactness that precludes psychological analysis. And the more natural the process by which the storyteller forgoes psychological shading, the greater becomes the story's claim to a place in the memory of the listener, the more completely is it integrated into his own experience, the greater will be his inclination to repeat it to someone else.

BENJAMIN, supra note 6, at 91 .

Arendt indeed repeats verbatim Grynszpan's testimony and does not paraphrase or summarize it, as she did with K-Zetnik's discourse. Arendt is so remarkably and deeply moved by Grynszpan's testimony that she steps out of her boundaries and (for a moment) pleads against her own legal objection to the victim's story and against her own puristic, legalistic emphasis on strict legal relevance:

This story took no more than perhaps ten minutes to tell, and when it was over-the senseless, needless destruction of twenty-seven years in less than twenty-four hours-one thought foolishly: Everyone, everyone should have his day in court. Only to find out, in the endless sessions that followed, how difficult it was to tell the story, that-at least outside the transforming realm of poetry-it needed a purity of soul, an unmirrored, unreflected innocence of heart and mind that only the righteous possess. No one either before or after was to equal the shining honesty of Zindel Grynszpan.

ARENDT, supra note 10, at 229-30 (emphasis added). The reason Arendt is so overwhelmed with emotion, I would suggest, is that her own traumatic story of the loss of Germany is unwittingly, unconsciously reflected back to her from Grynszpan's modest story. This narrative of a forceful removal across national borders is also Benjamin's story (the cause of his death).

What is significant for my point here, however, is that Arendt describes Grynszpan in Benjamin's literal words. The apotheosis of Arendt's uncharacteristic pathos in this passage is a literal stylistic echo, a literal rhetorical and verbal reminiscence of Benjamin's concluding sentence in The Storyteller. Benjamin writes in his signature phrase: "The storyteller is the figure in which the righteous man encounters himself." BENJAMIN, supra note 6, at 109 (emphasis added). Similarly, resonantly, Grynszpan is described as having "a purity of soul" that "only the righteous possess." 
mentioned and his text is never cited in the book, Benjaminian words and formulations unwittingly pervade its pages like stylistic echoes that form an impassioned philosophical subtext under and through the irony, the wryness, and the dryness of the legalistic text. At stake in this subtext is a relation between death and writing, an intimately personal relation which the writing "I" cannot possess or formulate directly, but can relate to indirectly through Benjamin's reflection on the relation between death and storytelling. Benjamin's memory and presence - the presence of his death and of his text-unwittingly yet hauntingly, persistently inform Arendt's style and permeate her writing and her utterance. "Death," wrote Benjamin precisely in his essay, "is the sanction of everything that the storyteller has to tell. He has borrowed his authority from death."

Has Arendt in her turn borrowed her authority as storyteller of the trial from a legacy of death of which she does not speak and cannot speak? I will suggest indeed that, through its understated but repeated reference to the storyteller, Eichmann in Jerusalem is also Arendt's book of mourning. ${ }^{87}$ It is, in other words, a book-an unarticulated statement-on the relation between grief and justice, as well as on the counterparts of grief and justice in narrative and storytelling. "It is perfectly true," Arendt will write in Truth and Politics, "that "all sorrows can be borne if you put

ARENDT, supra note 10 , at 229.

Another reference to The Storyteller makes itself evident at the beginning of the book. In the first chapter, in one of her rare moments of self-inclusion, Arendt situates herself as part of the audience of the trial whose task it is "to face the storyteller."

[The audience] was filled with "survivors," with middle-aged and elderly people, immigrants from Europe, like myself, who knew by heart all there was to know, and who were in no mood to learn any lessons. ... [A]s witness followed witness and horror was piled on horror, they sat there and listened in public to stories they would hardly have been able to endure in private, when they would have had to face the storyteller.

Id. at 8 (emphasis added). Arendt here places herself significantly among the survivors, those who inadvertently share with those who took the stand with the knowledge of how difficult it is to tell the story of survival (to testify at once to life and to the death-the dying-the survival has entailed). The expression "to face the storyteller" (in which Arendt as a listener and as a survivor also faces herself) is reminiscent again of Benjamin's Storyteller, in which the listener becomes a storyteller in her turn. "For storytelling is always the art of repeating stories," writes Benjamin. "The more self-forgetful a listener is, the more deeply is what he listens to impressed upon his memory. . . [The listener] listens to the tales in such a way that the gift of retelling them comes to him all by itself." BENJAMIN, supra note 6, at 91. It is as though Arendt facing Eichmann in Jerusalem and judging the trial at the level of her statement were also at the same time, at the level of her utterance, listening to the whisper of Benjamin's voice reciting, as it were, The Storyteller from his deathbed (like the original narrator in his essay):

It is . . characteristic that not only a man's knowledge or wisdom, but above all his real lifeand this is the stuff that stories are made of-first assumes transmissible form at the moment of his death. Just as a sequence of images is set in motion inside a man as his life comes to an end, unfolding the views of himself under which he has encountered himself without being aware of it - suddenly in his expressions and looks the unforgettable emerges and imparts to everything that concerned him that that authority which even the poorest wretch in dying possesses for the living around him. This authority is at the very source of the story.

Id. at 94 (emphasis added).

86. BENJAMIN, supra note 6 , at 94 .

87. See ARENDT, supra note 10, at 6 ("Justice ... demands seclusion, it permits sorrow rather than anger."). 
them into a story or tell a story about them." and Arendt's critical rehearsal of it are preoccupied-albeit in different styles - with the translation of grief into justice. Both are therefore mirror images of the translation of grief into grievance as what underlies precisely the capacity and the significance of saying "I accuse," of crying out $J$ 'accuse in the name of those who can no longer say it. ${ }^{89}$

Eichmann in Jerusalem, I would suggest, is inhabited by Arendt's mourned and unmourned ghosts. Benjamin is one of those. (Another ghost, I would suggest, is Heidegger, but I will not dwell here on his ghostly significance in Eichmann in Jerusalem). ${ }^{90}$

In all language, Benjamin has argued, there is a lament that mutes it out." "In all mourning there is an inclination to speechlessness, which is infinitely more than the disinclination or the inability to communicate." 92 Benjamin's unmentioned name and subterranean presence as an inadvertent and complex subtext of Eichmann in Jerusalem is linked, I argue, both to Arendt's testimony in this book and to her silence, a silence which in turn is linked not just to her discretion but to her speechlessness, that is, to her own inability to tell a story. There is, in other words, a crucial story Arendt does not tell and cannot tell, which underlies the story of the trial she does tell. ${ }^{93}$

"Familiar though his name may be to us," wrote Benjamin,

the storyteller in his living immediacy is by no means a present force.

He has already become something remote from us and something which is getting even more distant .... Less and less frequently do we encounter people with the ability to tell a tale properly . . . . It is as if something that seemed inalienable to us ... were taken from us:

88. ARENDT, supra note 68 , at 262 . Arendt borrows this sentence from Isak Dinesen, "who not only was one of the great storytellers of all times but also-and she was almost unique in this respect-knew what she was doing." Id.

89. Cf. Prosecutor's Opening Statement, supra note 55. For an in-depth interpretation of this statement, see Felman, supra note 18.

90. I am arguing that Benjamin and Heidegger are the two absent addressees of Eichmann in Jerusalem (symbolically, the German-Jewish casualty and the compromised German philosopher: a lost friendship and a lost love).

91. "Even where there is only a rustling of plants," Benjamin writes lyrically, "there is always a lament. Because she is mute, nature mourns ... [and] the sadness of nature makes her mute." 1 WALTER BENJAMIN, On Language as Such and on the Language of Man, in SELECTED WRITINGS, 1913-1923, at 73 (Marcus Bollock \& Michael W. Jennings eds., Edmund Jephcott trans., 1996).

92. Id.

93. This speechless story is a story of mourning and of the inability to mourn: the story of a trauma and of the trauma's silencing and willful disavowal. In the middle of the writing of Eichmann in Jerusalem, Arendt also had a violent car accident from which she almost died: Another brutal inner rupture, another intimate relation to death which similarly, equally was silenced and has left no visible mark on the tight argument of the book. Arendt tells Jaspers about this fatal accident:

It seemed to me that for a moment I had my life in my hands. I was quite calm: death seemed to me natural, in no way a tragedy or, somehow, out of the order of things. But, at the same time, I said to myself: if it is possible to do so decently, I would really like, still, to stay in this world. Quoted in YouNG-BRUEHL, supra note 83, at 335 (emphasis added). 


\section{the ability to exchange experiences. ${ }^{94}$}

Benjamin intuitively knew that the inability to tell a story was related to the essence of traumatic experience. ${ }^{95}$ Specifically, he linked this inability to tell to the collective, massive trauma of the war. "Was it not noticeable at the end of the war that men returned from the battlefield grown silentnot richer, but poorer in communicable experience?"96

Benjamin spoke of the First World War. ${ }^{97}$ K-Zetnik's testimony at the Eichmann trial showed how people have returned even more tonguetied-even poorer in communicable experience, grown even more silentfrom the death camps and from the traumatic nightmare of the Second World War. "When I got out of Auschwitz," writes K-Zetnik, "they went with me, they and the silent blocks, and the silent crematorium, and the silent horizons, and the mountain of ashes." $" 98$

I would argue differently from Arendt (and with hindsight she could not possess) that (unpredictably, unwittingly) it was the inadvertent legal essence and legal innovation and uniqueness of the Eichmann trial, and not its testimonial accident, to voice the muteness generated by the Holocaust and to articulate the difficulty of articulation of the catastrophic story, the difficulty of articulation and the tragic unnarratability of the ungraspable disaster and of its immeasurably devastating, unintelligible trauma. The impossibility of telling is not external to this story: It is the story's heart. ${ }^{99}$ The trial shows how the inherent inability to tell the story

94. BENJAMIN, supra note 6 , at 83.

95. "It is only for convenience that we speak of . . 'traumatic memory," writes the psychiatrist Pierre Janet. "The subject is often incapable of making the necessary narrative which we call memory regarding the event; and yet he remains confronted by a difficult situation in which he has not been able to play a satisfactory part." Quoted in Van der Kolk \& Van der Hart, supra note 43, at 160 (emphasis added).

96. BENJAMIN, supra note 6 , at 84 .

97. On Benjamin's relation to the First World War and on the role of silence and of trauma in his work, see Shoshana Felman, Benjamin's Silence, 25 CRITICAL INQUIRY 201 (1999).

98. KA-TZETNIK, supra note 12 , at 18 (translation modified by author according to Hebrew original, supra note 12 , at 34 .

99. The importance of the story element in trials is by now a commonplace in legal scholarship. What is less well known is that, to the extent that trauma is what cannot be narrated (Benjamin, Janet), it also incorporates the paradoxical story of an inherent resistance to storytelling. Every trauma thus includes not only a traumatic story but a negative story_element, an anti-story. I argue that the Eichmann trial is an unprecedented legal event that articulates at once a monumental legal story and a collective, monumental anti-story, the unanticipated story of the impossibility of telling.

On trauma theory as incapacity for narration, see, e.g., Van der Kolk \& Van der Hart, supra note 43; CARUTH, supra note 43. For general discussions of the relation between law and narrative, see, e.g.,

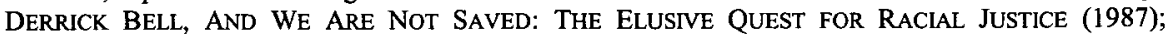
CRITICAL RACE THEORY: THE CUTTING EdGE (Richard Delgado ed., 1995); CRITICAL RACE THEORY: THE KEY WRITINGS THAT FORMED THE MOVEMENT (Kimberlé Crenshaw, Neil Gotanda, Gary Peller \& Kendall Thomas eds., 1995); LAW's STORIES: NARRATIVE AND RHETORIC IN THE LAW (Peter Brooks \& Paul Gewirtz eds., 1996); NARRATIVe AND THE Legal Discourse: A ReADER IN STORYTElLING AND THE LAW (David Ray Papke ed., 1991); NARRATIVE, VIOLENCE AND THE LAW: THE ESSAYS OF ROBERT COVER (Martha Minow, Michael Ryan \& Austin Sarat eds., 1995); RoBIN West, Narrative, AUthority, AND LAW (1993); Patricia Williams, The AlChEMy of RaCE AND RIGHTS: DIARY OF A LAW PROFESSOR (1991); Kathryn Abrams, Hearing the Call of Stories, 79 
is itself an integral part of the history and of the story of the Holocaust. The function of the trial thus becomes precisely to articulate the impossibility of telling through the legal process and to convert it into legal meaning. ${ }^{100}$

My conception of the trial is, then, fundamentally different from that of Arendt. Logically speaking, it is, however, Arendt's text that has helped me to read the trial differently from her. It is precisely Arendt's own surprised insistence on "how difficult it was to tell the story"101 and her own excessive utterance- - her own haunted allusions to Benjamin and to The Storyteller - that have contributed to shape my own perspective. All along, I have been reading Arendt's text to understand what was unique (peculiar) in the trial and to gain an insight into what was happening in the courtroom through the magnifying lens of Arendt's sharp and critically insightful eyes. In this last chapter, I have suggested that besides the criticism there is also an unspoken element of grief in Arendt's text, that a relation between grief and justice indirectly and unconsciously informs Arendt's utterance, and that it is precisely this excessiveness of Arendt's utterance over her statement that gives her book authority and gives her text a literary depth, an existential density and a political and legalphilosophical charisma that go beyond the conscious terms of her spoken argument.

I wish now to draw out this unspoken potential of Arendt's text and to pursue it further in my own (quite different) way. In the remainder of my argument, I will go farther than Arendt does in drawing on the haunting relevance of Benjamin to Eichmann in Jerusalem and more generally, in using Benjamin's reflection to highlight important aspects of the trial. Although I will, from this point on, use Benjamin to read the trial differently from Arendt (to argue with and argue beyond Arendt), my different understanding and my different proposition, to the extent that

CAL. L. REV. 971 (1991); Richard Delgado, Storytelling for Oppositionists and Others: A Plea for Narrative, 87 MICH. L. REV. 2411 (1989); James R. Elkins, On the Emergence of Narrative Jurisprudence: the Humanistic Perspective Finds A New Path, 9 LEGAL STUD. F. 123 (1985); James R. Elkins, The Quest for Meaning: Narrative Accounts of Legal Education, J. LEGAL EDUC. 577 (1988); Daniel A. Farber \& Suzanna Sherry, Telling Stories Out of School: An Essay on Legal Narratives, 45 STAN. L. REV. 807 (1993); Felman, supra note 41; Mari Matsuda, Looking to the Bottom: Critical Legal Studies and Reparations, 22 HARV. C.R.-C.L. L. REV. 323 (1987); Austin Sarat, Narrative Strategy and Death Penalty Advocacy, 31 HARV. C.R.-C.L. L. REV. 353 (1996); Richard Sherwin, Law Frames: Historical Truth and Narrative Necessity in a Criminal Case, 47 STAN. L. REV. 39 (1994).

100. Because the unanticipated force of the event of the impossibility of telling caught everyone off guard and must have been surprising even to the trial's architects and to its legal actors, Arendt treats it as a symptom of their oversight and of their failure. I see it as a proof of the success of their conception beyond their grasp.

In the same way that K-Zetnik's fainting could not be foreseen and was not planned, the legal narrative of the impossibility of telling could not be planned. It had to happen. It was the human and the legal meaning of what happened. But no one could articulate this meaning at the time. It was the unanticipated essence of the event, not part of the trial's stated ideology. It is only now in retrospect that this significance comes into view and can be recognized and formulated.

101. ARENDT, supra note 10 , at 229. 
they rely in turn on Benjamin's authority and on his haunting presence, will also paradoxically be speaking with Arendt's text and from her storyteller's silence: from the unconscious pathos of her own excessive and yet silenced, muted, self-erased and self-transcendent utterance.

\section{LX}

\section{The Dramatic}

In the wake of Benjamin, I argue therefore that the testimonial muteness underlying (and exceeding) Arendt's legal story reenacts, ironically enough, the literary muteness of K-Zetnik's story, and that K-Zetnik's legal muteness - his inability to tell a story in the trial - is part of the impossibility of telling at the trial's heart. Indeed, K-Zetnik's discourse prior to his fainting strives to thematize precisely the impossibility of telling, both in its use of the figure of "the other planet," 102 testifying to the utter foreignness of Auschwitz and trying to convey the astronomic scale of distance separating its ungraspability and unnarratability from the narration in the courtroom in Jerusalem, and in its effort to narrate the scene of the extermination as a repeated scene of parting and of silence, a primal scene of silence whose sole meaning wordlessly resides in the exchange of looks between the living and the dying: between the not-yetdead and the not-yet-surviving who remain behind for no other purpose than to tell and to retell the story that cannot be told.

But K-Zetnik's testimony does not simply tell about the impossibility of telling: it dramatizes it - enacts it -through its own lapse into coma and its own collapse into a silence. "It was the most dramatic moment of the trial," writes Tom Segev, "one of the most dramatic moments in the country's history." 103

For Arendt as a critical legal observer and as a conscious representative of the traditional conception of the law, however, ${ }^{104}$ the dramatic as such is by definition immaterial and extraneous to the trial. Arendt's view follows the classical axioms of jurisprudential thought. The process of the law, says Justice Oliver Wendell Holmes in one of the most authoritative statements of Anglo-Saxon jurisprudence in the twentieth century, "is one, from a lawyer's statement of the case, eliminating as it does all the dramatic elements ... and retaining only the facts of legal import, up to the final analyses and abstract universals of theoretic jurisprudence." 105

102. Id. at 223-24.

103. SEGEV, supra note 14, at 4 (emphasis added).

104. I now return from the "subtext" of Eichmann in Jerusalem to Arendt's conscious and explicit text: her conscious critical report as a legal historian of the trial.

105. Oliver Wendell Holmes, The Path of the Law, Address delivered at the dedication of the new hall of the Boston University School of Law (Jan. 8, 1897) reprinted in 110 HARV. L. REV. 991 
This precisely is what Arendt tries to do, in discarding the dramatic and in theorizing in her legal proposition about the Eichmann trial the "abstract universal" of a new crime and of a new criminal without mens reawithout motive. "The banality of evil" is, in fact, strictly a "theoretical jurisprudential" concept: an antiseptic legal concept that is formed by the strict reduction of the drama that has given rise to its conceptual necessity. "If a man goes into law," says Holmes, "it pays to be a master of it, and to be a master of it means to look straight through all the dramatic incidents." 106

Arendt therefore unambiguously discards the dramatic in the trial and denies it legal meaning. I would argue here, in contrast, that the dramatic can be legally significant. I submit that in the Eichmann trial (as the passing comment of the judges has in fact conceded) the dramatic was indeed endowed with legal meaning, meaning that the classical jurisprudential, legalistic view was programmed to miss and that Arendt consequently overlooked.

"As Hannah Arendt and others have pointed out," writes Susan Sontag:

[T] he juridical basis of the Eichmann trial, the relevance of all the evidence presented and the legitimacy of certain procedures are open to question on strictly legal grounds.

But the truth is that the Eichmann trial did not, and could not, have conformed to legal standards only .... The function of the trial was rather that of the tragic drama: above and beyond judgement and punishment, catharsis.

[T[he problem with the Eichmann trial was not its deficient legality, but the contradiction between its juridical form and its dramatic function. ${ }^{107}$

Arendt herself acknowledged in the epilogue of Eichmann in Jerusalem that, as the saying goes, "justice must not only be done but must be seen to be done." 108 The legal function of the court, in other words, is in its very moral essence, a dramatic function: not only that of "doing justice," but

(1997)

106. Id. at 1006 . "When we study law," Holmes asserts, "we are not studying a mystery." Id. at 991. Eichmann's banality, Arendt insists, and the banality of Nazism as a whole, is not a mystery. Its essence is its shallowness, its hollow lack of depth. And this, says Arendt, is why "it is in the nature of this case that we have no tools to hand except legal ones, with which we have to pass sentence on something that cannot even be adequately represented either in legal terms or in political terms." Letter from Arendt to Jaspers (Dec. 23, 1960), in CORRESPONDENCE, supra note 20, at 417. The tool is purposely, revealingly reductive: "When we study law we are not studying a mystery."

107. Sontag, supra note 63, at $118-19$ (emphasis added).

108. ARENDT, supra note 10, at 277. 
that of "making justice seen" in a larger moral and historically unique sense. ${ }^{109}$ It was through the perspective of this larger cultural and historic visibility the trial gave dramatically, historically to justice that the Eichmann trial was (I would propose) jurisprudentially dramatic.

In a different context, Walter Benjamin in turn defines the dramatic:

The mystery is, on the dramatic level, that moment in which it juts out of the domain of language proper to it into a higher one unattainable for it. Therefore, this moment cannot be expressed in words but is expressible solely in representation: it is the "dramatic" in the strictest sense. ${ }^{110}$

Law in principle rules out what cannot be disclosed in words. In contrast, the dramatic, Benjamin says, is a beyond of words. It is a physical gesture by which language points to a meaning it cannot articulate.

Such is K-Zetnik's fall outside the witness stand. It makes a corpse out of the living witness who has sworn to remain anonymous and undifferentiated from the dead.

I argue that the witness's body has become within the trial what Pierre Nora would call "a site of memory." "In opposition to the trial's effort to create a conscious, totalizing memory and a totalizing historical consciousness, the site of memory is an unintegratable, residual unconscious site that cannot be translated into legal consciousness and into legal idiom. This site materializes in the courtroom memory of death both as a physical reality and as a limit of consciousness in history.

On this legal site, the witness testifies through his unconscious body. Suddenly, the testimony is invaded by the body. The speaking body has become a dying body. The dying body testifies dramatically and wordlessly beyond the cognitive and the discursive limits of the witness's speech.

The body's testimony thus creates a new dimension in the trial, a physical legal dimension that dramatically expands what can be grasped as legal meaning. I argue that this new dimension in its turn transforms and dramatically reshapes not just the legal process of the Eichmann trial, but the conception and the very frameworks of perception of the law as such.

109. In this sense, the Eichmann trial did fulfill its function, even in Arendt's critical eyes. "Those who are convinced that justice, and nothing else, is the end of law will be inclined to condone the kidnapping act, though not because of precedents." Id. at 264-65.

This last of the Successor trials will no more, and perhaps even less than its predecessors, serve as a valid precedent for future trials of such crimes. This might be of little import in view of the fact that its main purpose- to prosecute and to defend, to judge and to punish Adolph Eichmann-was achieved.

Id. at 272-73.

110. 1 WALTER BENJAMIN, Goethe's Elective Affinities, in SELECTED WRTTINGS, supra note 91, at 297, 355; (emphasis added).

111. Pierre Nora, Between Memory and History: Les Lieux de Mémoire, in 26 REPRESENTATIONS 7 (Mark Roudebush trans., 1989). 


\section{The Caesura of the Trial: The Expressionless}

How is it that the body can unconsciously transform the parameters of law as such? The witness's fainting - the body's dramatic collapse in the midst of the witness's verbal testimony-could strikingly exemplify within the structure of the trial what Walter Benjamin calls "the expressionless":

The life undulating in it [Benjamin writes, and I would specify: the life undulating in the trial] must appear petrified and as if spellbound in a single moment.... What... spellbinds the movement and interrupts the harmony is the expressionless. ... Just as interruption by the commanding word is able to bring the truth out of the evasions... precisely at the point where it interrupts, the expressionless compels the trembling harmony to stop .... For it shatters whatever still survives of the legacy of chaos ... the false, errant totality, the absolute totality. Only the expressionless completes the work [completes the trial], by shattering it into a thing of shards, into a fragment of the true world, into the torso of a symbol. ${ }^{112}$

To borrow Benjamin's inspired terms to describe the trial, I would argue that K-Zetnik's fainting and his petrified body stand for the "expressionless"-das Ausdruckslose-that suddenly irrupts into the language of the law and interrupts the trial. In Benjamin's terms, I would argue that K-Zetnik's collapse can be defined as "the caesura" of the trial $^{113}$ : a moment of petrification that interrupts and ruptures the articulations of the law, and yet that grounds them by shattering their false totality into "a fragment of the true world"; a sudden "counter-rhythmic rupture" in which (as Benjamin has put it) "every expression simultaneously comes to a standstill, in order to give free reign to an expressionless power." 114

The fainting that cuts through the witness's speech and petrifies his body interrupts the legal process and creates a moment that is legally traumatic not just for the witness, but chiefly for the court and for the audience of the trial. I argue in effect that, in the rupture of the witness's lapse into a coma, it is the law itself that for a moment loses consciousness. But it is through this breakdown of the legal framework that history emerges in the courtroom and, in the legal body of the witness, exhibits its own inadvertently dramatic (non-discursive) rules of evidence.

112. BENJAMIN, supra note 110 , at 340 .

113. Benjamin (using Holderlin's terms) speaks of "the caesura of the work." Id. at 354, 340-41.

114. "Thereby, in the rhythmic sequence of the representations ... there becomes necessary what in poetic meter is called the caesura . . . . the counter-rhythmic rupture . . . that caesura in which, along with harmony, every expression simultaneously comes to a standstill, in order to give free reign to an expressionless power ...."Id. at 340-41. 
It is precisely through this breach of consciousness of law that history unwittingly and mutely yet quite resonantly, memorably speaks. ${ }^{115}$

And it is for these moments in which history as injury dramatically, traumatically has spoken-these moments that combined the legal, the dramatic, and the legally traumatic, yet whose eloquence and legal meaning could not be translated into legal idiom--that the Eichmann trial is remembered. It is precisely through these moments that the Eichmann trial has impressed itself on memory, as a remarkable legal event in which the law itself was shattered into a new level of perception and into a new historical and legal consciousness.

\section{PART FOUR: CONCLUSION}

This Essay has dealt with a legal moment that took the legal institution by surprise and stupefied at once the judges and the audience of the trial. In their written opinion, the judges marked the unique evidentiary position of this moment in the trial. They thought it was significant that it was a literary writer who collapsed, and that it was an artist's testimony that the trial exploded. Indeed, law has exploded here the literary framework. In turn, the conflation of the writer's literary testimony with the law has brought about a parallel explosion of the legal framework. Both the legal and the literary frameworks came apart as a result of their encounter in the trial. I argue that this breakdown-this caesura-was legally significant although (and because) it was legally traumatic.

This moment in which the human witness, flabbergasting both the audience and the judges, plunges into the abyss between the different planets and falls as though he were himself a corpse, is internal to the trial. I argue that it is a moment inside law, although its power comes from its interruption of the law, its interruption of discourse by what Walter Benjamin calls "the expressionless." The expressionless, I argue, grounds both the legal meaning of the trial and its inadvertent literary and dramatic power.

For the purpose of transmission of the Holocaust, literature and art do not suffice. And yet, a trial is equally insufficient. I believe that only the encounter between law and art can adequately testify to the abyssal meaning of the trauma.

It is remarkable that such an encounter between trauma, law, and art

115. It is as though, summoned to court, history acquired power of speech in amplifying and in making audible K-Zetnik's own repeated yet repeatedly mute cry. He writes:

That mute cry was again trying to break loose, as it had every time death confronted me at Auschwitz; and, as always when I looked death in the eye, so now too the mute scream got no further than my clenched teeth that closed upon it and locked it inside me. Indeed that was the essence of that cry: it was never realized, never exposed to the outside air. It remained a strangled flame inside me.

KA-TZETNIK, supra note 12, at 1-2 (translation modified by author according to Hebrew original, supra note 12 , at 18 ). 
happens inside a trial. Inside the trial, in the drama of the missed encounter between K-Zetnik and the legal actors (judge and prosecutor), there is a unique confrontation between literature and law as two vocabularies of remembrance. The clash between these two dimensions and these two vocabularies brings about a breakdown of the legal framework through the physical collapse of the witness. Yet, through this inadvertent breakdown of the legal framework, history uncannily and powerfully speaks. "Everything," said Benjamin, "about history that, from the very beginning, has been untimely, sorrowful, unsuccessful, is expressed in a face, ${ }^{116}$ or rather in a death's head." 117

This death's head emerges in the trial as history is uncannily transmitted through K-Zetnik's fainting and through his endlessly reverberating courtroom silence.

$* * *$

In borrowing the words of Lanzmann, I will therefore argue that what Arendt calls the failures ${ }^{118}$ of the trial were necessary failures. ${ }^{119} \mathrm{I}$ argue that the Eichmann trial dramatically articulated legal meaning that no legal categories could apprehend precisely through its failures. I further argue that it is in general a feature of pathbreaking trials to speak through the explosion of the legal framework, to legally say something (or show something) that is not containable precisely by the concepts and the logic of the legal. Moments of rupture of the legal framework can be-as they

116. Compare the strikingly resonant statements of the French philosopher Emmanuel Levinas: The relation to the face is all at once the relation to the absolutely weak-what is absolutely exposed, what is naked and what is deprived ... and at the same time ... the face is also the "Thou shall not kill"... It is the fact that I cannot let the other die alone, it is as though there were [from the face] an appeal to me .... For me, he is above all the one for which I am responsible. . . It is always from the face, from my responsibility for the other, that justice emerges.

Emmanuel Levinas, Philosophie, Justice, Amour, in ENTRE Nous: EsSai SUR Le PenSER À L'AUTRE 114-15 (1991) (author's translation) (emphasis added).

117. Walter Benjamin, The ORIGIN OF German Tragic Drama 166 (1985) (1966).

118.

And indeed, before we come to any conclusion about the success or failure of the Jerusalem court, we must stress the judges' firm belief that they had no right to become legislators, that they had to conduct their business within the limits of Israeli law, on the one hand, and of accepted legal opinion, on the other. It must be admitted furthermore that their failures were neither in kind nor in degree greater than the failures of the Nuremberg Trials or the Successor Trials in other European countries. On the contrary, part of the failure of the Jerusalem court was due to its all too eager adherence to the Nuremberg precedent . . . .

ARENDT, supra note 10, at 274 (emphasis added).

119. Asked what was his concept of the Holocaust, Lanzmann answered:

I had no concept. I had obsessions, which is different .... The obsession of the cold .... The obsession of the first time .... The obsession of the last moments, the waiting, the fear. Shoah is a film full of fear.... You cannot do such a film theoretically. Every theoretical attempt was a failure, but these failures were necessary. ... You build such a film in your head, in your heart, in your belly, in your guts, everywhere.

Interview with Claude Lanzmann at Yale University, New Haven, Conn. (May 5, 1986) (film and transcript available at Fortunoff Video-Archive for Holocaust Testimonies at Yale) (transcription at 22-23) (emphasis added). 
were, I argue, in the Eichmann trial-moments of legal and conceptual breakthrough. Moments of institutional collapse and of "caesura" of the legal discourse-such as during K-Zetnik's fainting - can be moments in which both art and history unwittingly speak in and through the legal tool. I offer this as food for thought: Great trials are perhaps specifically those trials whose very failures have their own necessity and their own literary, cultural, and jurisprudential speaking power. 